San Jose State University

SJSU ScholarWorks

Master's Theses

Master's Theses and Graduate Research

Summer 2017

\title{
Evaluation of Oyster Shell Enhancement on Western Snowy Plover Breeding Success
}

Karine Tokatlian

San Jose State University

Follow this and additional works at: https://scholarworks.sjsu.edu/etd_theses

\section{Recommended Citation}

Tokatlian, Karine, "Evaluation of Oyster Shell Enhancement on Western Snowy Plover Breeding Success" (2017). Master's Theses. 4865.

DOI: https://doi.org/10.31979/etd.6tx8-s5y5

https://scholarworks.sjsu.edu/etd_theses/4865

This Thesis is brought to you for free and open access by the Master's Theses and Graduate Research at SJSU ScholarWorks. It has been accepted for inclusion in Master's Theses by an authorized administrator of SJSU ScholarWorks. For more information, please contact scholarworks@sjsu.edu. 


\title{
EVALUATION OF OYSTER SHELL ENHANCEMENT ON WESTERN SNOWY PLOVER BREEDING SUCCESS
}

\author{
A Thesis \\ Presented to \\ The Faculty of the Department of Environmental Studies \\ San José State University \\ In Partial Fulfillment \\ of the Requirements for the Degree \\ Master of Science
}

by

Karine Tokatlian

August 2017 
(C) 2017

Karine Tokatlian

ALL RIGHTS RESERVED 
The Designated Thesis Committee Approves the Thesis Titled

\title{
EVALUATION OF OYSTER SHELL ENHANCEMENT ON WESTERN SNOWY PLOVER BREEDING SUCCESS
}

\author{
by \\ Karine Tokatlian \\ APPROVED FOR THE DEPARTMENT OF ENVIRONMENTAL STUDIES \\ SAN JOSÉ STATE UNIVERSITY \\ August 2017 \\ Lynne Trulio, Ph.D. \\ Department of Environmental Studies \\ Rachel O’Malley, Ph.D. Department of Environmental Studies \\ Cheryl Strong, M.S. Biology United States Fish and Wildlife Service
}




\title{
ABSTRACT \\ EVALUATION OF OYSTER SHELL ENHANCEMENT ON WESTERN SNOWY PLOVER BREEDING SUCCESS
}

\author{
by Karine Tokatlian
}

The Pacific Coast population of the western snowy plover (Charadrius nivosus nivosus; plover) is listed as a federally threatened species under the U.S. Endangered Species Act due to poor reproductive success from anthropogenic habitat loss, and high predation pressure. Plovers in the South San Francisco Bay use dry salt evaporation ponds, and wildlife-managed ponds, to breed and winter. However, the South Bay Salt Pond Restoration Project aims to restore up to 6,110 hectares of this habitat back to native tidal marsh, which will force plovers to breed in smaller areas and in higher densities. In order to recover plovers in these unique conditions, remaining habitat can be enhanced using oyster shells, which may camouflage breeding plovers, and decrease predation. This study evaluated the effect of oyster shell enhancement on plover breeding success by comparing nesting density, success, and brood behavior between enhanced and unenhanced areas. Plovers did select to nest in enhanced areas; however, nest survival did not increase relative to unenhanced areas. Brood behavior was also affected by enhancement, though highly correlated with the location of optimal foraging habitat. It is likely that enhancement will only improve nesting success if predators are concurrently controlled. Ultimately, plovers may benefit from the application of oyster shells as it attracts nesting effort, and may be strategically used by resource managers. 


\section{ACKNOWLEDGMENTS}

This Master's Thesis is the result of the support and guidance of many individuals. First, thanks are due to Dr. Lynne Trulio, Dr. Rachel O’Malley, and Cheryl Strong for their invaluable guidance and expertise. Second, great appreciation is due to the San Francisco Bay Bird Observatory, namely Catherine Burns who initiated this study, and Yiwei Wang who provided analytical expertise. Thanks to the Don Edwards National Wildlife Refuge, California Department of Fish and Wildlife, and the South Bay Salt Pond Restoration Project, for supporting all aspects of this study. Particular thanks are due to Ducks Unlimited for funding the majority of this research through grants from Wildlife Conservation Board and California State Coastal Conservancy. Data were diligently collected by several biologists at the San Francisco Bay Bird Observatory, to whom I owe my gratitude. Finally, thank you to my family, Armine, Ludwig, and Jasmin Tokatlian, and Miroslav Weisner for their unwavering support. 


\section{TABLE OF CONTENTS}

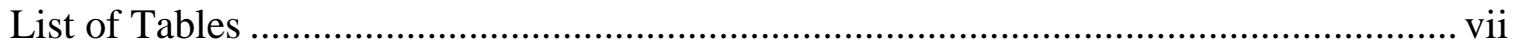

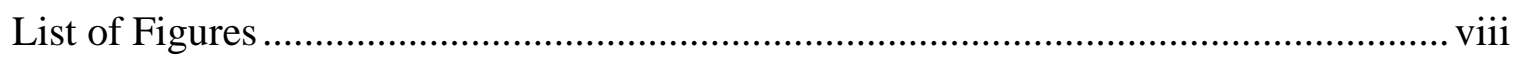

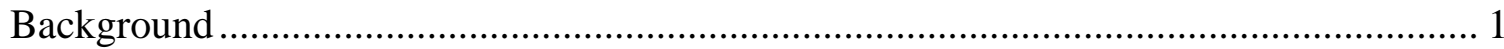

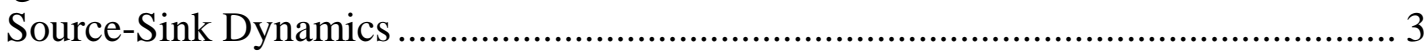

Anthropogenic Impacts and Habitat Fragmentation.................................................. 4

Snowy Plover Status and Biology ………………………………………….... 5

South San Francisco Bay Plover Population ............................................................ 9

South Bay Salt Pond Restoration Project .................................................................. 13

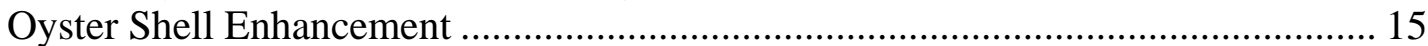

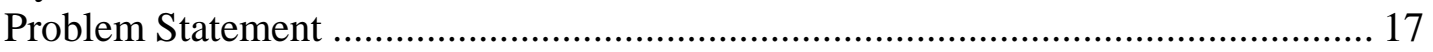

Objectives and Research Questions .................................................................. 18

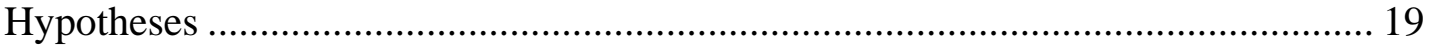

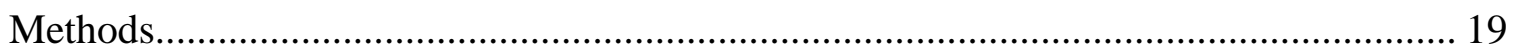

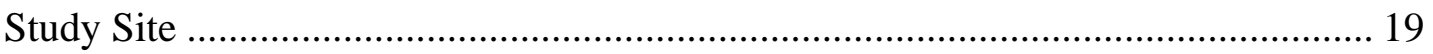

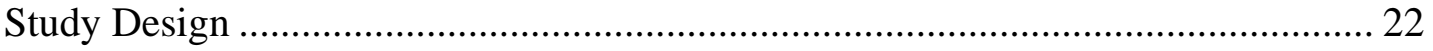

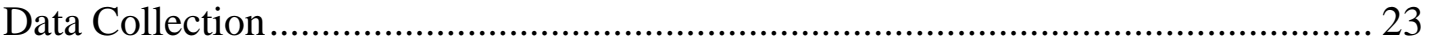

Observational Surveys................................................................................. 23

Nest Checks and Chick Banding ……………………….................................. 25

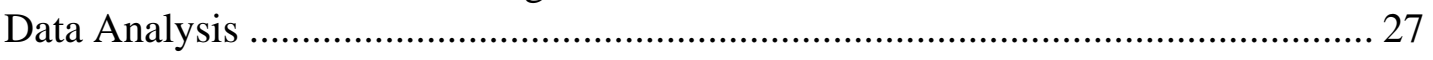

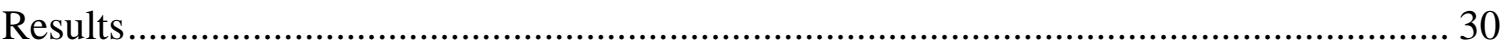

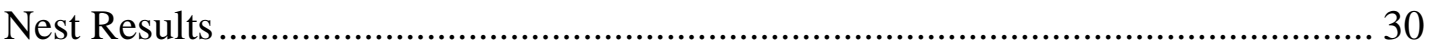

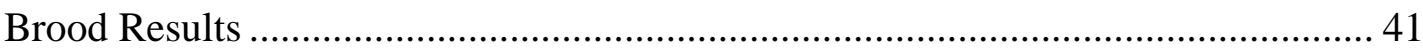

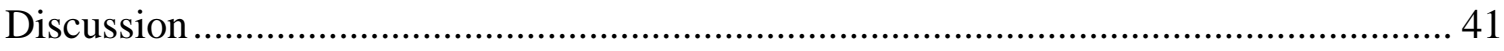

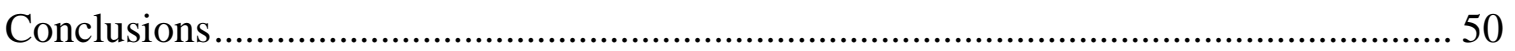

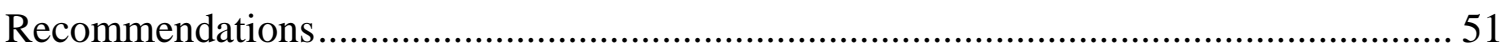

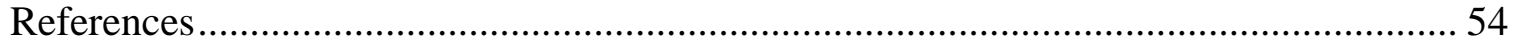




\section{LIST OF TABLES}

Table 1. Chi-square Analysis of Plover Nest Site Selection....................................... 35

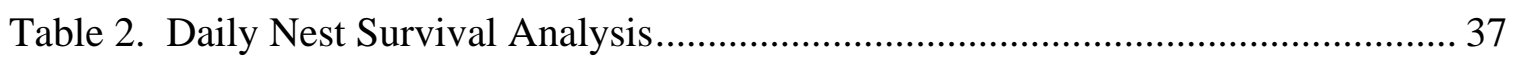

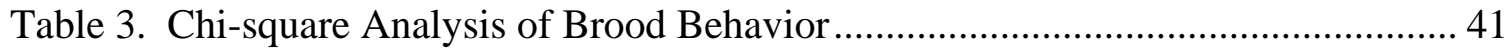




\section{LIST OF FIGURES}

Figure 1. Pond E14 study location within the South San Francisco Bay salt evaporation ponds, California.

Figure 2. Oyster shell enhancement plots in pond E14 with three treatment areas, Eden Landing Ecological Reserve, Alameda County, California.

Figure 3. Histogram showing the most common fate day for depredated nests in pond E14 in Eden Landing Ecological Reserve, Alameda County, California from 2015 to 2016.

Figure 4. The proportion of plover nest fates in pond E14 in Eden Landing Ecological Reserve, Alameda County, California. The number of nests is shown in parenthesis. 2014 data are included to provide a reference to pre-enhancement nesting success........ 30

Figure 5. The proportion of plover nests by fate in enhancement treatment plots (New 1 and New 2) and the Control area in pond E14 in Eden Landing Ecological Reserve, Alameda County, California in 2015 and 2016, combined..

Figure 6. The proportion of plover nests by fate in enhancement treatment plots (New 1, New 2, Control) in pond E14 in Eden Landing Ecological Reserve, Alameda County, California in 2015 and 2016, separately. The number of nests is shown in parenthesis. 32

Figure 7. The proportion of plover nest fates in one-hectare pilot study plots in pond E14 in Eden Landing Ecological Reserve, Alameda County, California. The number of nests is shown in parenthesis. Plots were spread in 2008.

Figure 8. The average weekly nest density (number of nests per area in hectares) in pond E14 in Eden Landing Ecological Reserve, Alameda County, California, from 2015-16. Error bars represent standard error.

Figure 9. Principal component analysis factor scores characterizing nest sites on each nest's $20^{\text {th }}$ day of activity in pond E14 Eden Landing Ecological Reserve, Alameda County, California, from 2015-16.

Figure 10. Daily nest survival rates of nests within treatment plot New 1 as affected by time (days over season), in pond E14 from 2015 to 2016. Estimate represents DSR. .... 38

Figure 11. Daily nest survival rates of nests within treatment plot New 2 as affected by time (days over season), in pond E14 from 2015 to 2016. Estimate represents DSR. .... 39

Figure 12. Daily nest survival rates of nests within Control plot as affected by time (days over season), in pond E14 from 2015 to 2016. Estimate represents DSR. 39 


\section{Background}

More than 10,000 bird species are identified worldwide (Brusca \& Brusca, 2003). Birds offer many ecosystem services through predator-prey relationships, and by maintaining ecological balances between trophic levels (Dasmann, 1968; Sekercioglu, 2006). Birds are also key members of natural and agricultural communities, and they support genetic productivity through pollination, seed dispersal and natural pest control (Sekercioglu, 2006; Van Bael et al., 2008). Without birds, pollination and growth of floral communities would be severely impacted, and some ecological systems would collapse. As a result of the deep connection to their ecological communities, birds are excellent indicators of environmental health. By studying their status, ecologists can measure qualities of biodiversity and productivity (Gregory, 2006).

Unfortunately, many bird species are threatened by anthropogenic activities, particularly since the advent of the industrial age (Worster, 1977). Many bird populations are declining as a direct result of human development and activity (Diamond, 2005; Krech, 2009; Moyle \& Orland, 2004), and human development is the leading source of ecological change (Schlacher et al., 2007; Steffen et al., 2007). Studying the ecological impacts of human development on affected species is essential for managing struggling populations in order to gauge their adaptability, or management needs, as their environments change (Cohen et al., 2007; Rodenhouse et al., 1997).

Land availability for natural communities has decreased as a result of human development, and much of the remaining natural habitat has become fragmented (Benitez-Lopez et al., 2010). Coastal beaches and bay areas are highly desirable 
locations for human development, largely due to their aesthetic value and metropolitan activity (Schlacher et al., 2007). Development in these areas changes coastal and tidal transition zones, and replaces open spaces with business parks, housing, shopping and recreational infrastructure (Chace \& Walsh, 2006). Habitat loss and fragmentation prevents wildlife from being able to move continuously through their home ranges and to access food resources, essentially confining them to smaller areas (Johnstone et al., 2010). Birds that depend on open, undisturbed areas for survival are under considerable threat as their natural resources are manipulated and removed.

Increased human activity also disrupts ecological balances between trophic levels (Raudsepp-Hearne et al., 2010). Predatory generalist species like corvids, gulls, and scavenging mammals are now thriving in human-subsidized environments, rich with excess food and waste (Harding et al., 1998; Jiménez \& Conover, 2001; Meckstroth \& Miles, 2005; Walker \& Marzluff, 2015). In contrast to sensitive species, these predatory animals are highly adaptable and opportunistic. The modern human lifestyle of convenience generates an enormous amount of waste that can serve as a constant food resource for opportunistic species (e.g. landfills, dumpsters, recreational areas; Ackerman et al., 2013). As predator populations grow, greater pressure is applied to their prey. Sensitive bird species now experience stress from increased rates of predation, in addition to declining habitat availability.

One species declining due to habitat loss and predator pressure is the western snowy plover (Charadrius nivosus nivosus; plover). This small shorebird breeds along the Pacific coast on sandy beaches and in the San Francisco Bay, but its rangewide 
population is struggling under increasing predation pressure as opportunistic predators thrive in human-dominated habitats (U. S. Fish and Wildlife Service [USFWS], 2007). Plovers in the San Francisco Bay are faced with the additional challenge of habitat loss due to a large tidal marsh restoration effort, which will benefit a different suite of endangered species and ecosystem services (South Bay Salt Pond Restoration Project [SBSPRP], 2011). In order to achieve plover recovery, it is critical to develop effective management actions that will improve plover breeding success in the San Francisco Bay.

\section{Source-Sink Dynamics}

A number of theoretical models can be used to assess population dynamics of plovers in the face of human-caused habitat changes. One such theory is the source-sink model in which higher quality habitats act as biological sources, creating higher natality rates, while lower quality habitats act as biological sinks, creating higher mortality rates (Dias, 1996; Harveson et al., 2004). A sink can only persist if members of the source population move and contribute to it. Identifying priority habitat patches (sources) is essential when assessing a population's survival, particularly one that has been geographically fragmented by natural or anthropogenic factors (Cohen et al., 2007;

Rodenhouse et al., 1997). Identifying sinks is equally important for management to avoid wasting resources by supporting such habitats, or by attracting wildlife to them. A recent Population Viability Analysis (PVA; Hudgens et al., 2013) showed that breeding plover colonies in the San Francisco Bay are largely stable, while those in northern portions of the range are likely sinks, and those in southern portions are likely sources. 
An outgrowth of source-sink dynamics is the ecological trap theory which suggests that animals can be led to poor quality habitats, but are highly attractive as a result of rapid environmental change. Ecological traps are essentially "attractive sinks" (Battin, 2004). Rapid changes in habitat can create false cues which attract individuals to an environment that reduces survivorship, or is not suitable during migration or breeding seasons (Robertson \& Hutto, 2006). These rapid changes can be natural (ex: habitat alteration by fire), or anthropogenic (ex: agricultural fields, airports; Best, 1986; Kershner \& Bollinger, 1996). Traps may occur on both spatial and temporal scales. Over time, these habitats become sinks as their quality appears rich, but they are realistically unable to support a sustainable or successful population. Since the ecological trap theory was developed by Dwernychuk and Boag (1972), further investigation suggests that this problem is highly pervasive due to human disturbance (Battin, 2004; Schlaepfer et al., 2002). As more natural habitats are altered and fragmented, populations are lead to poor quality habitats and eventually begin to struggle, which elevates the need for conservation management.

\section{Anthropogenic Impacts and Habitat Fragmentation}

Anthropogenic activity can significantly impact natural ecosystems and their wildlife communities (Blair, 1996; Emlen, 1974), altering species abundance and composition (Jones et al., 2005; Marzluff et al., 2001). Habitat fragmentation is one mechanism that can cause population declines. Historical fragmentation is a natural phenomenon produced by geological shifts, fire, or climate changes (Foster, 1980; Wright, 1974). 
However, rampant human activity such as large scale deforestation, development, and agriculture is rapidly accelerating fragmentation (Burgess \& Sharpe, 1981).

Natural habitats that were once continuous are now fragmented, which has created smaller sub-habitats. Natural routes of migration may no longer persist as populations are limited to smaller territories and, in many cases, are genetically confined to their subhabitats (Wilcox \& Murphy, 1985). Remaining populations retreat to available but shrinking patches, and suffer effects of crowding and increased competition (Andren, 1994). Portions of viable habitat are entirely destroyed, access to food resources becomes limited, and the overall quality of resources declines.

Wildlife populations often struggle as a result of habitat fragmentation. This is the most common cause of threatened or endangered species status (IUCN, 2016). Limited resources and unnaturally small territories make populations more susceptible to fluctuations in external factors, like weather or disease (Haddad et al., 2015). Once natural and correctable, these population fluctuations now have potentially disastrous consequences. The need for conservation and management of impacted species becomes strikingly clear as more populations are affected by the pressure of habitat change. One species in need of conservation management due to anthropogenic change is the western snowy plover.

\section{Snowy Plover Status and Biology}

The snowy plover (Charadrius nivosus) is a small shorebird found on coastal beaches, dry alkaline ponds, and lakes (American Birding Association, 1957). The snowy plover was formerly considered a conspecific of the Eurasian kentish plover 
(Charadrius alexandrinus), but advances in genetic analysis detected strong morphological and genetic divergences between the two, and supported the recognition of three distinct subspecies of snowy plover (Funk et al., 2007). In recent years, genetic analysis yielded further reclassification of one group as a distinct species of snowy plover (Charadrius nivosus; Kupper et al., 2009). Furthermore, the snowy plover population found on the North American Pacific Coast is classified as a separate subspecies, the western snowy plover (Charadrius nivosus nivosus), genetically distinct from the population found in interior states.

Breeding and wintering habitats of the Pacific Coast population of the western snowy plover (plover) range from Washington State to Baja Sur, Mexico (Pearson et al., 2008). They use sparsely vegetated expanses of coastal beach or dry alkaline ponds to roost, forage and breed (Muir \& Colwell, 2010). Plovers feed on terrestrial and marine invertebrates and are polyandrous breeders, laying multiple nests during the breeding season. Plovers rely on cryptic behavior and appearance (color and pattern of plumage and eggs) as a survival mechanism in order to evade detection from predators (Page et al., 2009). Adult males raise their hatchlings while females leave the brood to find another mate. Due to their precocial nature, plover hatchlings are able to move and forage independently within 1-3 hours after hatching (Boyd, 1972), requiring only warmth, protection, and direction to suitable habitats from the adult male parent.

On coastal beaches, plover adults and chicks can move several hundred meters from their nests within the first 1-3 days after hatching (Wilson \& Colwell, 2010). Although young plover chicks are self-sufficient in many ways, the energetic cost of movement 
toward safe foraging and roosting locations is taxing (Johansson \& Blomqvist, 1996), and may expose them to higher rates of predation. Adult and young plovers require environments that connect nesting habitats with nearby foraging habitats which include sources of water in order to survive.

Human manipulation of natural habitats has substantially disrupted the ecosystems upon which plovers depend (USFWS, 2007). The North American Pacific Coast has undergone extreme habitat changes as human populations became more metropolitan, increasing from $28 \%$ in 1910 to $80 \%$ in 2000 (Hobbs \& Stoops, 2002). Western U.S. development grew faster than any other region throughout the country, and consistently grew during each decade of the $20^{\text {th }}$ century. As a result, plover habitat has become increasingly fragmented since the 1900s, and by 1970, plover breeding adults were absent from many historical nesting locations throughout southern California (Page \& Stenzel, 1981). Without adequate or continuous breeding habitat and access to quality resources, the plover population has struggled to maintain sustainable population levels (USFWS, 2007).

In 1993, the Pacific Coast population of the western snowy plover (plover) was listed as threatened under the Endangered Species Act of 1973 (U. S. Fish and Wildlife Service [USFWS], 1993) and a species recovery plan was completed in 2007 (USFWS, 2007). The species recovery plan identifies anthropogenic habitat degradation from urban development, disturbance, non-native species introduction, and expanding predator populations as the primary causes of decline (USFWS, 2007). Six geographicallydefined Recovery Units have been identified along the Pacific coast, each with specific 
criteria for recovery based on population histories. In order to remove plovers from the list of endangered and threatened wildlife, resource managers must increase population numbers across the range through intensive monitoring and management of threats.

Criteria for delisting the plovers are stated in the species recovery plan. Firstly, the range-wide plover population must increase to 3,000 birds, and that number should be maintained for at least ten years (USFWS, 2007). Population goals within individual Recovery Units are defined in more detail in the recovery plan; the San Francisco Bay represents Recovery Unit three with a goal of maintaining 500 breeding individuals. Secondly, each male plover should annually fledge an average of one (1.0) chick; this annual productivity must be maintained for five years. A PVA used to inform the 2007 species recovery plan treated the plover population as a metapopulation, defined as a "set of subpopulations among which there is limited dispersal" (Nur et al., 1999). Although the population in each recovery unit is somewhat isolated and genetically limited, no one population appeared to function as a distinct segment at the time (Nur et al., 1999).

A more recent PVA found that both plover adult survival and fecundity were higher in southern recovery units and lower in northern recovery units (Hudgens et al., 2013), indicating subpopulations south of Point Reyes National Seashore were most likely population sources, and those north might be population sinks (Hudgens et al., 2013). The San Francisco Bay plover subpopulation is identified as large, somewhat stable, and is neither a source nor a sink.

Plovers throughout their range and within the San Francisco Bay are primarily impacted by predation and habitat loss (USFWS, 2007). Within the San Francisco Bay, 
$42 \%$ of plover nests were predated over the last decade (annual average; Tokatlian et al., 2014). Populations of generalist predator species, like corvid and gull, have become unnaturally high due to human activity and access to anthropogenic resources like refuse and agriculture fields (Boarman \& Berry, 1995; Hansson, 1997; Restani et al., 2001). Though predation is a natural component of the breeding cycle, inflated predator populations present extreme impacts on more sensitive prey species (Webb et al., 2004). In order to reach range-wide plover recovery goals of sustaining 3,000 breeding plovers over ten years, habitats will need to be restored and enhanced, while intensive predator management regimes are maintained throughout the range (Hudgens et al., 2013).

\section{South San Francisco Bay Plover Population}

Historically, plovers bred and wintered on Pacific coastal sandy beaches. Since the early 1900s they have also used comparable habitat in the South San Francisco Bay region (USFWS, 2007). Natural tidal wetlands in the South San Francisco Bay (South Bay) were developed and converted into salt production pond systems beginning in the late 1800s (Cohen \& Carlton, 1998; Nichols et al., 1986). As native tidal marsh habitat was lost, plovers began foraging and breeding on flat expanses of panne created for evaporative salt production (which appear beach-like), and the population grew (USFWS, 2007).

Specimen evidence (Grinnell et al., 1918) suggests that plovers historically wintered in the San Francisco Bay prior to salt pond construction; however, it is less clear if plovers nested here as well (Ryan \& Parkin, 1998). Historically, small salt pannes developed naturally as bay water became trapped in the marsh, which then crystalized as 
the sun and prevailing winds evaporated remaining bay water (Brown, 1960). Salt was harvested from these small pannes, called "hot ponds", and from marsh grasses by native Ohlone tribes (Mofras, 1844). As settlers arrived in the San Francisco Bay and took notice of this natural resource, it became increasingly valuable for trade. Salt ponds were first intentionally created in the San Francisco Bay by non-native settlers in 1854, eventually claiming more than $85 \%$ of the San Francisco Bay's natural tidal wetland (San Francisco Bay Conservation and Development Commission [SFBCDC], 2005).

The rapid conversion of tidal marsh into large expanses of salt ponds likely supported a growing plover population in the new anthropogenic environment. Breeding plovers in the South Bay currently use dry ponds to roost, forage, breed, and raise their chicks (USFWS, 2007; Tokatlian et al., 2014). In 1974, the Don Edwards San Francisco Bay National Wildlife Refuge (Refuge) was created by Congress with the acquisition of 12,000 acres of salt pond habitat in the South Bay (San Francisco Bay Wildlife Society, 2015).

As South Bay habitat was heavily claimed for anthropogenic purposes, natural marshes and wetlands were diked and enclosed to create complex systems of salt evaporation ponds. Though these ponds are largely unnatural and have locally eradicated many native tidal marsh species, their structure and diverse saline compositions have come to support a significant number of migrating shorebirds and waterfowl along the Pacific Flyway (Accurso 1992; Page et al., 1999; Warnock et al., 2002). The Western Hemisphere Shorebird Reserve Network lists the San Francisco Bay, including its salt 
ponds, as a site of hemispheric importance, hosting over one million shorebirds annually during migration (Page et al., 1999; Paulson, 1993; SFBCDC, 2005;).

In 1992, the United States Fish and Wildlife Service (USFWS) began monitoring plovers in the South Bay and by 2003, had established a collaborative monitoring and recovery effort with governmental and research organizations in the South Bay (Tokatlian et al., 2014). The South Bay plover population is currently stable (Hudgens et al., 2013). Maintaining this population stability in the central portion of the range, or improving population growth, is essential for supporting more sustainable range-wide plover numbers.

The average plover population size in the San Francisco Bay is 194 breeding individuals (2007-2016; Pearl et al., 2015). Four salt pond complexes are used by plovers to breed and winter: Eden Landing Ecological Reserve (Eden Landing) in Alameda County which is managed by California Department of Fish and Wildlife (CDFW); Fremont in Alameda County, Ravenswood in San Mateo County, and Alviso in Santa Clara County which are managed by the Don Edwards Refuge (Tokatlian et al., 2014; USFWS, 2007).

Nearly $64 \%$ of all breeding plover adults in the South Bay are found in Eden Landing each year (Tokatlian et al., 2014). Pond E14 has historically been an important plover breeding area, and from 2012-2014 hosted an annual average of 43\% of nests found in Eden Landing, and an annual average of $26 \%$ of nests found in the South Bay (Pearl et al., 2016). Plover breeding effort is consistently high in pond E14 compared to neighboring ponds and complexes. The average annual nest success rate (nests which 
hatch at least one egg out of all nests laid) in pond E14 is 54\%, comparable to plover nest fates throughout the South Bay. Depredation is the only significant cause of nest failure in pond E14, responsible for an average 58\% of nest fates from 2007 to 2016; few nests are abandoned or flooded each year (Pearl et al., 2015; Tokatlian et al., 2014; USFWS, 2007).

Avian and mammalian predators are consistently documented in South Bay plover breeding habitat; however, evidence documenting direct impacts to plovers is limited. One study conducted by Robinson-Nilsen, et al. (2011) using nest cameras revealed plover nests predated by common raven (Corvus corax), American crow (Corvus brachyrhynchos), red-tailed hawk (Buteo jamaicensis), peregrine falcon (Falco peregrinus), northern harrier (Circus cyaneus), California gull (Larus californicus), and grey fox (Urocyon cinereoargenteus). A similar range of predator species was documented predating American avocet and black-necked stilt nests in the South Bay, including red-tailed hawk, common raven, California gull, grey fox, rat (Rattus sp.), striped skunks (Mephitis mephitis), raccoon (Procyon lotor), and opossum (Didelphimorphia sp., Ackerman et al., 2006).

California gulls, the most abundant nesting bird in the South Bay, are an especially concerning predator. In 2015, the South Bay supported 38,000 breeding California gulls (Tarjan \& Butler, 2016), a dramatic increase from only 50 breeding individuals in 1980. In addition to plover nests, researchers have documented California gulls predating American avocet chicks, and black-neck stilt chicks (Ackerman et al., 2006). This 
human-subsidized predator has put unnaturally high pressure on more sensitive nesting shorebirds.

Similarly, common raven (raven) is a species of concern, as North American populations have increased by $166 \%$ over the last 40 years (BirdLife International, 2016; Butcher \& Niven, 2007). Ravens are generalists and have become abundant in California as endless anthropogenic food resources support high reproductive success, immigration, and survival (Webb et al., 2004). Corvids, particularly ravens, negatively impact plover breeding success throughout their range (Colwell et al., 2013; Pearson et al., 2014), and are documented plover nest predators in the San Francisco Bay (Demers \& RobinsonNilsen, 2012).

In order to improve plover breeding success in the South Bay, it is essential to determine an effective method of mitigating habitat loss, and keeping predator pressures at a tolerable level.

\section{South Bay Salt Pond Restoration Project}

In 2003, 6,110 hectares of salt pond habitat in the South Bay were acquired through the collective effort of several government and private organizations; they are currently managed by the USFWS and the CDFW. Much of this land was slated for tidal habitat restoration under the South Bay Salt Pond Restoration Project (the project), the largest tidal wetland restoration project on the North American West Coast (SBSPRP, 2011). Since 2003, these ponds have been managed to support a variety of wildlife in the South Bay, and a number of them are used as plover breeding habitat (Tokatlian et al., 2014). Breeding and foraging plover habitat is characterized as the dried, flat pond bottom, 
which becomes exposed when water is intentionally drained or seasonally evaporated out of the pond. Water levels are managed using water control gates; excavated channels, known as borrow ditches, run along pond perimeters and are surrounded by dirt levees.

The project goals are to restore at least $50 \%$ of the 6,110 pond hectares to natural tidal marsh, and to maintain the remaining acreage as managed pond habitat in the South Bay. This will provide flood protection, water quality improvements, and tidal marsh habitat restoration for many endangered and native species (Hobbs et al., 2015; SBSPRP, 2011). The plover, however, is a federally threatened species that has come to rely on shallow or dry pond habitat in order to breed and winter (Tokatlian et al., 2014). It will lose some of its important habitat to the project as ponds are converted to tidal marsh.

In 2008, project restoration actions in the Whale's Tail complex of Eden Landing (Figure 1) began; a system of six evaporation ponds in the northern portion of Eden Landing. Three ponds were restored completely to tidal action, and an additional two were re-designed as managed ponds to support multiple waterbird species. This resulted in the loss of approximately 200 hectares of heavily-used plover breeding habitat. Therefore, the project and CDFW designated the remaining sixth pond (E14; 67 hectares) as plover habitat to be managed and maintained for both breeding and wintering individuals.

As a subset of the federal species recovery goal of maintaining 500 breeding plovers in the San Francisco Bay (USFWS, 2007), the project also defines a goal of maintaining 250 breeding plovers within the project footprint itself. In order to achieve both federal and project goals, breeding plover productivity must increase even as their habitat is 
decreasing. One method of improving productivity is through the enhancement of plover habitat quality, as predator management resources are annually limited. Using oyster shells as enhancement material may provide protective cover for adult plovers, eggs, and chicks, and may serve as an effective method to increase breeding productivity.

\section{Oyster Shell Enhancement}

Spreading oyster shells throughout breeding shorebird habitat may introduce camouflaging color and texture, thereby protecting plover adults, nests, and chicks in bare habitats. It is thought that this method will assist species reliant on cryptic behavior and morphology for survival. In recent years, researchers have applied oyster shells in South Bay ponds as a preliminary study on improving breeding plover productivity (Robinson-Nilsen \& Demers, 2010).

Studies on coastal sandy beaches have suggested that oyster shell enhancement may encourage plover nest site selection after the removal of invasive vegetation (Zarnetske et al., 2010). In one vegetation removal area at Leadbetter Point, Washington, oyster shells were spread to provide camouflage for nesting plovers and to control the blowing of sand (Pearson et al., 2009). This enhancement attracted nearly all of the breeding plovers at Leadbetter Point to nest in oyster shell enhanced areas. Plover nest numbers, however, reached a limit even as the size of oyster shell enhanced areas increased, suggesting that nest numbers were controlled by other factors like predator pressure.

After studying plover nest site selection and site characteristics at an oyster shellenhanced colony in Hayward, California, researchers found that plovers selected sites with a higher percentage of oyster shell substrate, more oyster shells, and greater surface 
area of shells compared to control sites (Riensche et al., 2015). Dinsmore et al. (2014) found that habitat management (including vegetation removal and oyster shell application) nearly doubled plover nest success in Oregon.

The USFWS spread oyster shells and driftwood at Alameda Point to mitigate the effects of an accidental fuel oil spill, and to enhance nesting habitat for the endangered California Least Tern (Sterna antillarum brownii; California Department of Fish and Wildlife [CDFW], 2011). After monitoring the area for several years, results showed that terns rapidly colonized the enhanced area and nest numbers within the enhanced area rose quickly over a three-year period. Reproductive success was high when measured six years after enhancement, at a fledge rate of 0.97 fledges per pair (CDFW, 2011). Least terns continue to nest annually at Alameda Point using oyster shell enhancement.

The San Francisco Bay Bird Observatory (SFBBO) conducted a pilot study beginning in 2009 to test the effect of oyster shell enhancement on improving plover nest success (Robinson-Nilsen \& Demers, 2010). One-hectare oyster shell pilot plots (Pilot plots) were spread in five Eden Landing ponds (E16B, E8, E6A, E6B, and E14) in the winter of 2008. Three plots were spread in pond E14 at this time, however plover nests were not found within them until 2012. Preliminary studies in the South Bay have shown that plover nesting success is higher in oyster shell-enhanced areas than non-enhanced areas (Robinson-Nilsen et al., 2013). These promising results were the foundation for a larger scale application studied in this thesis. 


\section{Problem Statement}

In order to support the federally threatened Pacific coast population of the western snowy plover, it is important to maintain and improve the habitat that the species requires to breed successfully. When breeding habitat is removed or degraded, enhancement methods can be used to attract plovers and to promote successful reproduction in the habitat that remains. This may offset negative impacts of habitat loss (O'Neal et al., 2008; Pearson et al., 2009). Without the appropriate amount and quality of breeding habitat, the number of breeding individuals, nesting success, and species recovery goals will not be met (USFWS, 2007). Plovers in the South Bay utilize artificial habitat in the form of managed ponds, however project goals are designed to restore at least 3,000 hectares of this habitat back to natural tidal marsh habitat. Roughly $20 \%$ of ponds annually used by breeding plovers have been lost as a result of tidal marsh restoration activity (Tokatlian et al., 2014); an additional $8 \%$ are slated for conversion in upcoming project activities. As plover habitat continues to be lost to project actions, more plovers will need to use smaller remaining areas in order to reach the population reproductive metrics required for species recovery.

One potential method for enhancing breeding habitat in the South Bay is the application of oyster shells in remaining plover habitat, which may increase breeding success and nest density. The use of large oyster shells in bare, open habitat has been shown to provide additional cover for breeding plovers in order to evade detection from predators, and to increase nesting success in other locations (Robinson-Nilsen et al., 2013, Zarnetske et al., 2010). However, project actions have currently enhanced 370 
hectares of plover habitat in the South Bay, and their effectiveness with respect to plover reproductive success must be evaluated.

More data are needed to address the efficacy of oyster shell enhancement on improving plover breeding success, particularly by monitoring breeding plover activity in enhanced and non-enhanced areas. Comparing breeding metrics like nest success, nest survival, nest location, and brood behavior, between enhanced and unenhanced areas will indicate whether oyster shell application had a positive impact on breeding success.

If oyster shell enhancement increases plover breeding success, this method may be used to support plovers in the footprint of the project as well as throughout their range. This research may also quantify a nesting density limit in the South Bay which could then be used to identify the minimum amount of habitat required to reach species recovery and project goals. Such metrics can be used during future project phases by projecting how many must remain as plover habitat. This information will help resource managers balance the needs of species with disparate ecological requirements while achieving restoration goals.

\section{Objectives and Research Questions}

To contribute to the management of the western snowy plover (plover) population in the South San Francisco Bay (South Bay) this research will address the following questions and hypotheses researching the effect of oyster shell habitat enhancement on plover nest success:

RQ1: Do enhanced sites have higher proportions of nests that hatch compared to nonenhanced sites? 


\section{Hypotheses}

Ho1: Plover nest site density or selection do not differ between oyster shell enhancement sites and non-enhanced sites.

$\mathrm{Ho}_{2}$ : Plover nest site characteristics, such as distance to nearest nest, distance to nearest levee, and nest camera presence do not differ between enhanced areas compared to nonenhanced areas.

$\mathrm{Ho}_{3}$ : Plover daily nest survival rates do not differ between oyster shell enhanced areas and non-enhanced areas.

Ho4: Plover brood behavior does not differ between oyster shell enhanced areas and nonenhanced areas.

\section{Methods}

\section{Study Site}

This study was conducted within one salt evaporation pond, E14, in the South San Francisco Bay (South Bay), California. Pond E14 is located in the Eden Landing Ecological Reserve in Alameda County, California (37 36’31.23”N $\left.122^{\circ} 7^{\prime} 30.54^{\prime \prime} \mathrm{W}\right)$, in an area known as the "Whale's Tail Complex". Pond E14 is 67 hectares in size and is owned and managed by California Department of Fish and Wildlife (Figure 1). 


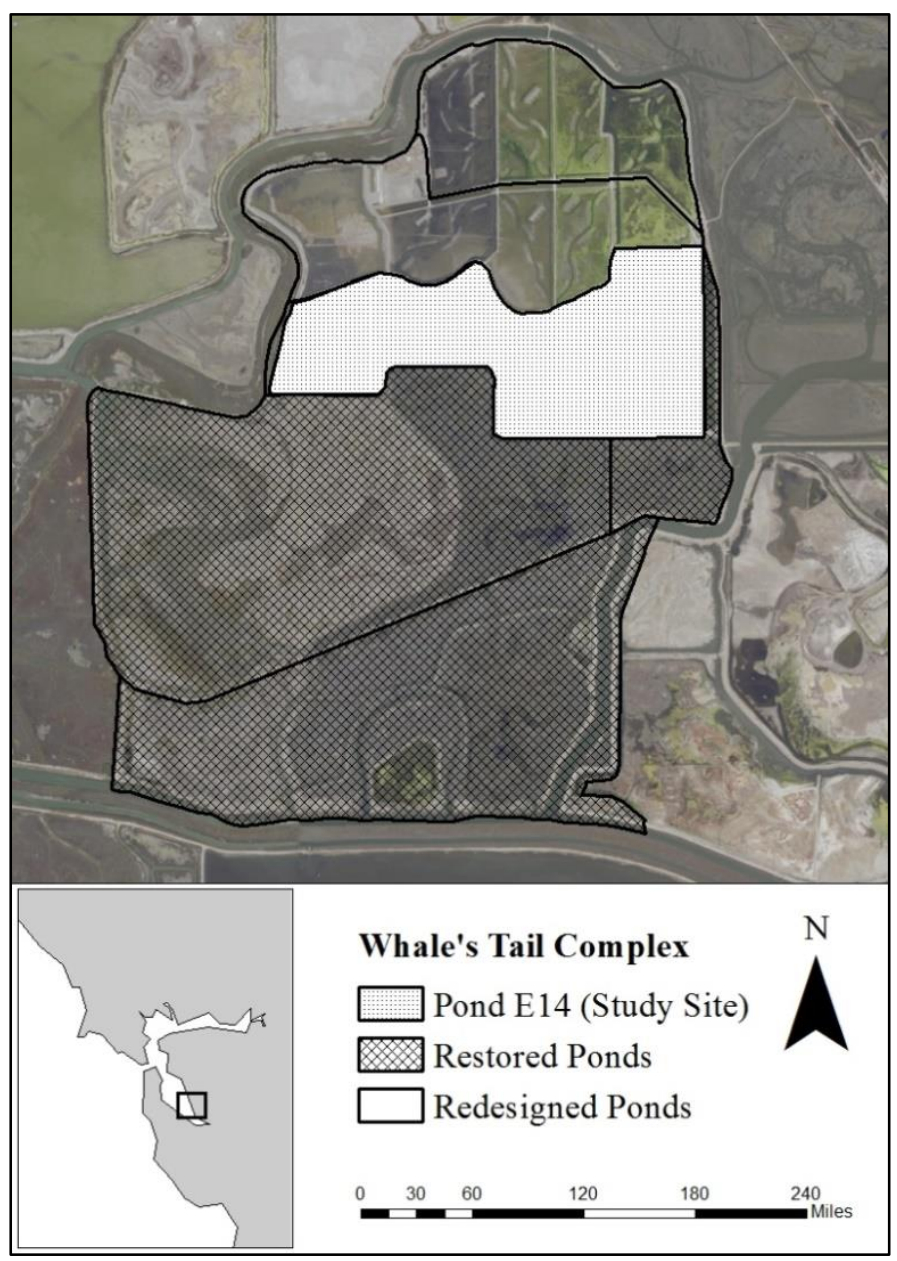

Figure 1. Pond E14 study location within the South San Francisco Bay salt evaporation ponds, California.

Alameda County has a Mediterranean climate with moderate, dry conditions in the spring and summer months, and moderate, wet conditions in the fall and winter. The study habitat is a diked former salt evaporation pond characterized by bare, largely nonvegetated substrate surrounded by a water channel and dirt levee. Common plant species surrounding pond habitat are pickleweed (Salicornia spp.), alkali-heath (Frankenia salina), saltgrass (Distichlis spicata), and many non-native weeds. 
Three one-hectare Pilot plots were spread in E14 in the winter of 2008 by SFBBO, as part of the pilot study which contributed to this research (Robinson-Nilson et al., 2013; Figure 2).

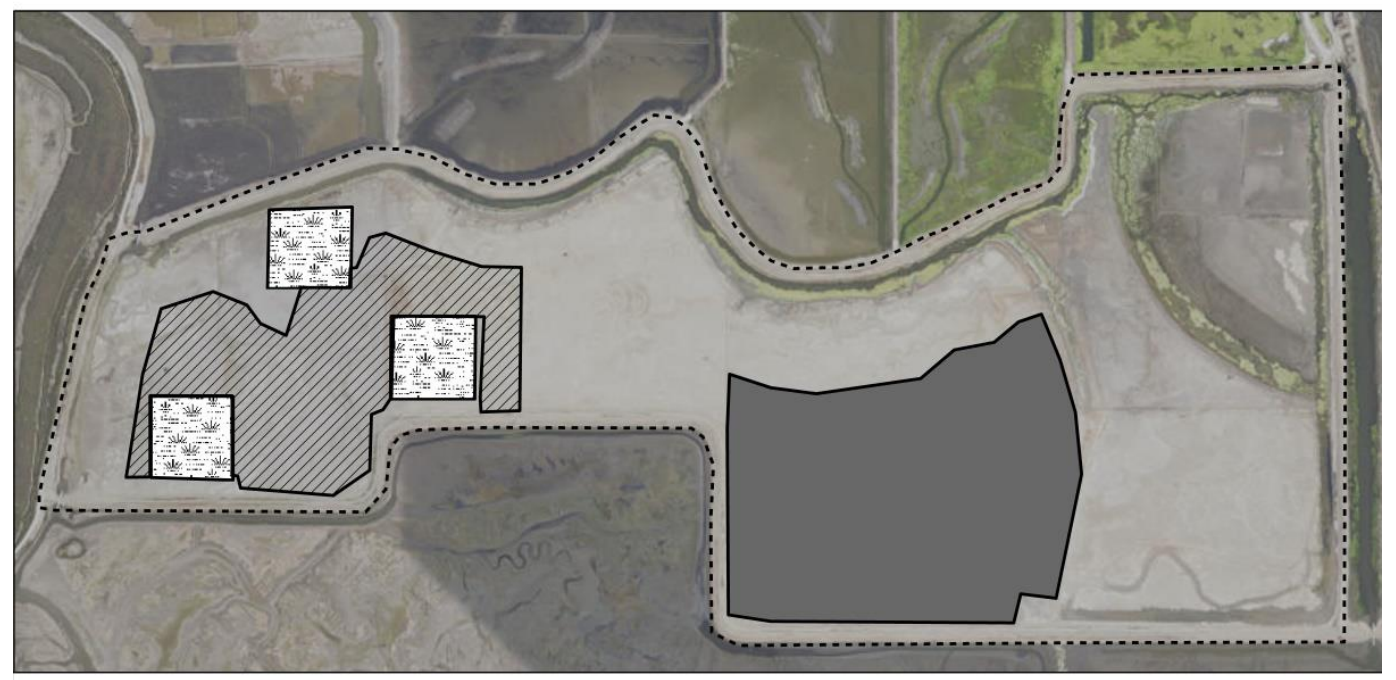

Pond E14 Oyster Shell Treatment Plots

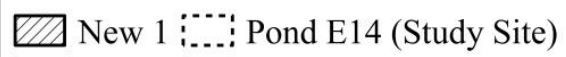

New 2 1-hectare Pilot Study Plots

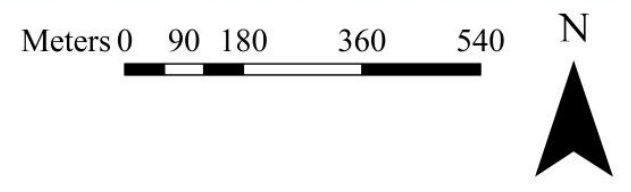

Figure 2. Oyster shell enhancement plots in pond E14 with three treatment areas, Eden Landing Ecological Reserve, Alameda County, California.

To enhance the remaining designated plover habitat, two large oyster shell enhancement plots were additionally distributed on the pond bottom of E14 (Figure 2) in September 2014 by CDFW and Ducks Unlimited. This was done as part of the project to enhance habitat to support the same number of plovers on a smaller footprint while restoring tidal habitats.

E14 oyster shell plot areas total 23.2 hectares; the western plot (termed New 1) measures 6.47 hectares, the eastern plot (termed New 2) measures 13.76 hectares, and the 
one-hectare pilot plots (termed Pilot) measure a total of 3 hectares; all remaining untreated areas were termed Control (Figure 2). The enhancement configuration was designed by SFBBO and CDFW. Oyster shell enhancement (23.2 hectares) covers roughly one third of the entire E14 pond area. All oyster shells spread in pond E14 were purchased or donated from Drake's Bay Oyster Company, Marin County.

\section{Study Design}

To investigate the effects of large scale oyster shell enhancement on breeding plovers, all breeding plovers in pond E14 were monitored during the 2015 and 2016 breeding seasons (March 1 to September 15). All survey and data collection methods were designed by Tokatlian and SFBBO management in 2014 to provide data to USFWS, CDFW and the project for plover recovery and management. All activities of this study were fully covered by required federal and state permits, including 1) Endangered Species Act 10(a)1(A) permit allowing the handling and take of protected plovers, 2) U.S. Geological Survey (USGS) banding permit allowing the handling and banding of plover adults and chicks, 3) California state Scientific Collection Permit, and 4) CDFW site access permit to Eden Landing. Work was conducted under SJSU IACUC permit number 1030 .

Collected data were designed to assess the effects of large scale oyster shell enhancement on breeding plover success by comparing breeding variables in enhanced and unenhanced area; variables included nest fate, nest initiation and fate date, distance to nearest levee (m), distance to nearest neighbor (m), and brood behavior. Each monitored nest was a sampling unit for assessing enhancement effects on nest and hatching success. 
Each monitored brood was a sampling unit for evaluating enhancement effects on brood behavior.

A hatched nest was defined as a nest that hatched at least one egg. Apparent nest success was defined as the percentage of hatched nests out of total nests laid. A fledged chick was defined as a chick that reached 31 days of age and flight capable. Apparent fledging success was defined as the percentage of banded chicks that reached fledge age out of the total number of chicks banded within pond E14 during both study seasons. A brood was defined as a group of plover chicks and their respective adult male and/or female that raised those chicks to fledge.

\section{Data Collection}

Survey methods were largely observational and conducted from the perimeter of the pond to minimize disturbance to sensitive breeding plovers. Non-observational methods, including weekly nest checks and banding activities, required physically walking within pond E14 and treatment areas. This was done as efficiently as possible, both spatially and temporally, and in accordance with all permitting regulations.

\section{Observational Surveys}

Three observational surveys (nest counts, brood counts, and brood behavior) were conducted once a week from March 1 to September 15 during the 2015 and 2016 breeding seasons. I, or another SFBBO biologist trained in these methods, performed surveys by driving the perimeter of pond E14 and using spotting scopes (Kowa Prominar TSN-664) and binoculars (various models). Observational surveys began at sunrise and continued until the entire pond was surveyed. Time limits and predetermined observation 
points were not established for nesting surveys; brood and brood behavior survey start locations varied throughout the season, beginning at either New 1 or New 2, to avoid bias of brood sample selection (Tokatlian et al., 2014).

All plovers detected within the pond were monitored during nesting surveys. Data collected included: date, time of each observation, status of each bird detected (male, female, chick by age $[\mathrm{C} 1=<2$ weeks, $\mathrm{C} 2=>/ 2$ weeks, $\mathrm{C}=$ unknown age $]$, juvenile, unknown), location relative to treatment type, behavior (roosting, foraging, incubating a nest, copulation or nest construction, other), and the distance to the nearest source of water in meters (estimated using topographic maps with a 50-sq meter overlaid grid). Field readable band combinations and the specific location of each bird on a topographic map were recorded.

During brood surveys, the following data were recorded for each detected brood: date, time of observation, status of each bird within brood (male, chick by age $[\mathrm{C} 1=<2$ weeks, $\mathrm{C} 2=>/ 2$ weeks, $\mathrm{C}=$ unknown age]), treatment type they are found in, behavior (roosting, foraging, brooding, other), and distance of each bird from the nearest source of water in meters. Field readable band combinations and the specific location of each brood on a topographic map were recorded. A brood behavior survey was concurrently conducted during which recorded detailed behavior data of the first four broods detected during each survey. The behaviors (roosting, foraging, brooding, in transit, stressed or aggressive) of both adults and chicks were recorded during 30 second intervals, for a duration of 20 minutes each (Rose \& Nol, 2010). 
Wildlife trail cameras (Reconyx PC900) were placed near individual plover nests and distributed equally within treatment and non-treatment areas to document predation events, problematic predator species or individuals, and to confirm nest fates. Cameras were placed directly on the ground approximately eight feet from each selected nest, housed in camouflage cases, and made less conspicuous by placing oyster shells, wood, and debris on and around them. Three rapid-fire still images were taken by motion sensor, in color by day and monochrome infrared by night. Cameras were checked by researchers during weekly nest checks.

To determine if predator species or individuals had learned to associate cameras with active plover nests, cameras were also placed at random locations where there was not a plover nest within all treatment areas. A predator was defined as any species that could potentially prey on plover nests, chicks or adults (Tokatlian et al., 2014; USFWS, 2007). Nest Checks and Chick Banding

All known and new nests were checked weekly after observational surveys had been completed to avoid researcher impacts. Researchers walked to each nest in order to collect the following data: exact nest location using a handheld GPS unit (Garmin GPS 60 ), treatment type of nest location (New 1, New 2, Control), adult presence at nest (incubating, not incubating, unknown), nest condition (intact, disturbed), nest fate (hatched, depredated, abandoned, other [including flooded or unknown]), and float measurements of each egg present (degree or diameter) in order to calculate age and hatch date (Hays \& LeCroy, 1971). 
To study the use of treatment areas and to estimate fledging success, a sample of all breeding plovers in pond E14 were banded, based on staff availability during hatch events. Current and standard banding techniques detailed by the Bird Banding Laboratory (BBL; Gratto-Trevor, 2004; Gustafson et al., 1997) were used for plover adults and chicks. Precocial plover chicks permanently leave the nest site within 6-12 hours after hatching, therefore chicks were captured at the nest site within a few hours of hatching, given time to dry and gain strength enough to be handled. Adults were captured at either dawn or dusk using noose mats placed around the nest (Mehl et al., 2003).

Each mat consisted of monofilament nooses (3.63 kg test fishing line) attached to strips of 6-mm wire mesh, each mat measuring 0.5 feet by 3 feet (Mehl, et al., 2003). Mats were placed in a triangle formation or a square formation, and were secured to the ground using large metal staples. The nest site was left and observed from a distance to ensure that selected males would walk across the noose mat when returning to their nest. Once the male was captured, the male was immediately retrieved and banded (Gustafson, et al., 1997).

Once captured, a unique four-color band combination was applied to each plover. Each band combination consisted of three darvic or acetal color bands and one silver USGS numbered band. Two bands were placed on each leg, below the tibio-tarsal joint, on the tarsus (Gratto-Trevor, 2004; Gustafson et al., 1997). Each plastic band was opened, slid onto the tarsus, and closed using a soldering iron; bands were then covered with color pin-striping tape. The metal USGS band was applied to the left leg below a 
single plastic band, and wrapped in auto pin-striping tape to serve as the fourth colored band. The average handling time for each adult was 10 minutes.

Adults and chicks were immediately returned to their capture site (nest) once banding was complete. Banders then left the area to a safe distance on the levee or within a vehicle in order to confirm that adults returned to tend the sensitive chicks. No adults or chicks were injured or abandoned during this study.

\section{Data Analysis}

Descriptive statistics were used to quantify the effect of oyster shell habitat enhancement on overall nest success and nest success by treatment area. Overall proportion of nest fates throughout pond E14 in 2015 and 2016 (regardless of enhancement type) were first compared to pre-enhancement conditions in 2014. Then the proportion of nest fates were calculated (hatched, depredated, abandoned, other

[including flooded or unknown])) relative to each treatment area (New 1, New 2, Control) for 2015 and 2016, including and excluding pilot study plots to determine substantial differences.

Nest densities were calculated for the entire pond and by treatment area (New 1, New 2, Control) by dividing the number of nests found within each area by the available habitat. Pilot plots were included with New 1 due to their close geographic proximity. Changes in available dry breeding habitat in E14 due to changing water levels were incorporated in density calculations.

Statistical tests were conducted using R and SPSS. A chi-square analysis was used to assess differences in plover nest site selection by treatment type (Manly et al., 2002); four 
models were examined. Nests found in Pilot plots were lumped with New 1 in some models due to their close geographic proximity. The four models were as follows:

1. All nests in all treatment types (New 1 [including pilot study plots], New 2, Control).

2. All nests in New 1 [including pilot study plots] and New 2

3. Nests in all treatment types (New 1 [excluding pilot study plots], New 2, Control).

4. Nests in New 1 (excluding pilot study plots) and New 2.

The observed variable was the proportion of all nests by each treatment type; the expected variable was the proportion of available area in each treatment type out of the total pond area.

A principal component analysis was used to characterize nest sites on each nest's $20^{\text {th }}$ day of activity. This day was chosen after determining that it was the day when most nests were depredated from the sample, indicating an ecological importance at this point during the nest incubation phase (Figure 3).

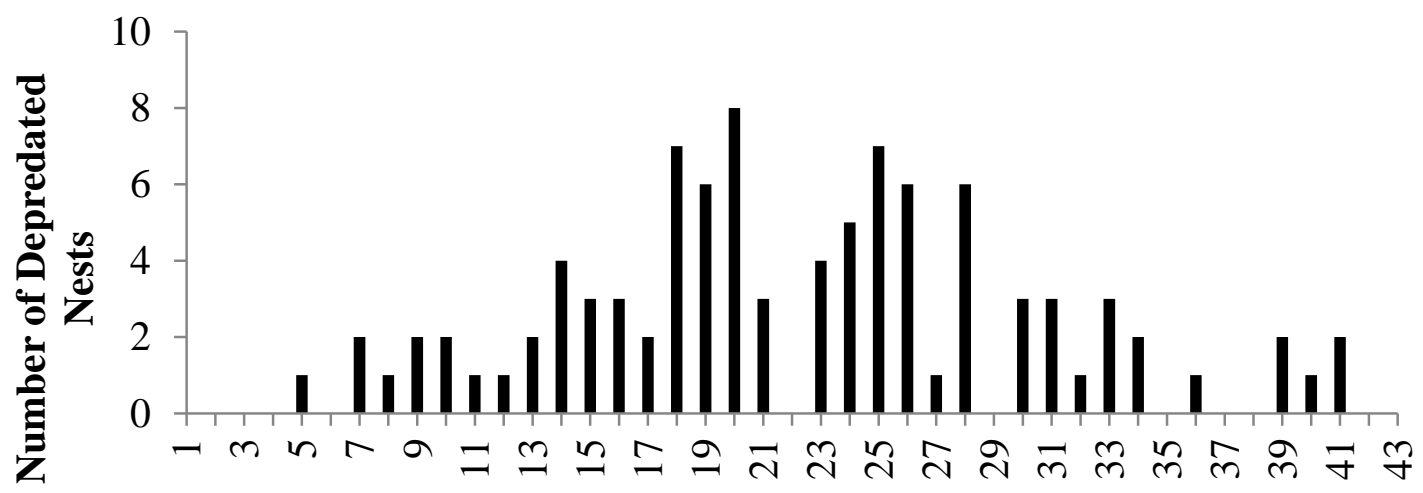

Nest's Day of Activity

Figure 3. Histogram showing the most common fate day for depredated nests in pond E14 in Eden Landing Ecological Reserve, Alameda County, California from 2015 to 2016. 
Input variables included treatment type (New 1 [including Pilot plots], New 2, Control), distance to nearest levee (m), distance to nearest neighbor (m), and nest camera presence. All variables were measured using spatial distribution tools in ArcGIS and Google Earth. Plover nests are active for 33 days (Page et al., 2009), meaning all nests were not simultaneously active each year; nest neighbor data were therefore calculated by week.

A nest survival analysis was conducted in program R (RMark; Rotella, 2016); encounter histories were created for each nest using 1) date the nest was found, 2) last date the nest was known to be present, 3) date the nest was last checked, and 4) nest fate date. Each encounter history also included year, treatment type (New 1, New 2, Control, Pilot), camera presence, and distance to nearest levee (m) as additional covariates in order to determine their effect on nest survival rates. Confidence intervals containing zero are not significant; negative intervals show a decrease in survival and positive intervals show an increase in survival (Rotella, 2016). The constant daily nest survival rate was raised to the $33^{\text {rd }}$ power (to signify 33 days of the plover incubation period) in order to calculate the probability that a nest would survive throughout the entire incubation period.

A chi-square analysis was used to compare the frequency of brood behavior (foraging) based on treatment type (New 1, New 2, Control, and Pilot). A multiple proportions test was used to compare the proportion of foraging behavior by treatment. It is important to note that it was not possible to band all hatched chicks in pond E14, 
therefore all broods were not individually identifiable. Some unbanded broods may have been observed multiple times and included in analysis.

\section{Results}

\section{Nest Results}

A total of 186 plover nests were detected throughout pond E14 during this study in enhanced and non-enhanced areas combined. Ninety-eight nests were found in 2015 , $60 \%$ of which hatched, and 88 nests were found in 2016, 23\% of which hatched (Figure 3).

A total of 79 nests hatched throughout pond E14 from 2015-16, creating an overall apparent nest success rate of $42 \%$. Depredation impacts throughout pond E14 varied substantially, affecting 31 nests (32\%) in 2015 and 64 nests (73\%) in 2016 (Figure 4).

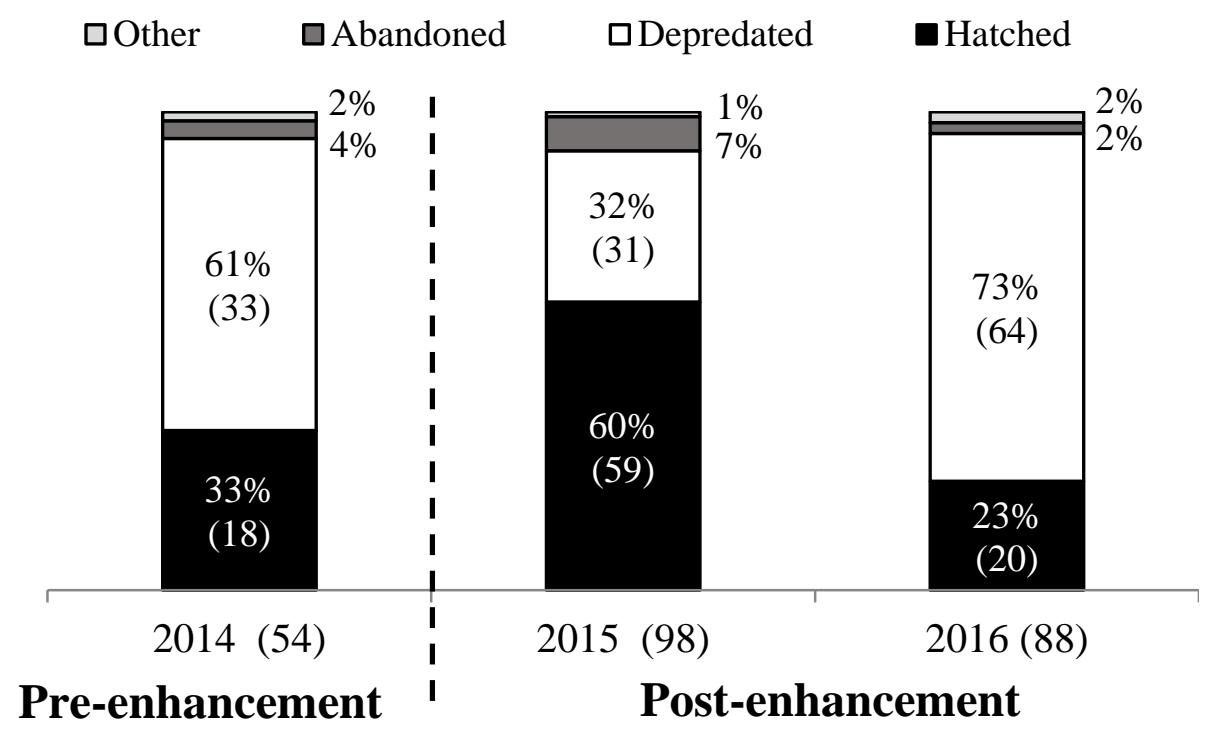

Figure 4. The proportion of plover nest fates in pond E14 in Eden Landing Ecological Reserve, Alameda County, California. The number of nests is shown in parenthesis. 2014 data are included to provide a reference to pre-enhancement nesting success. 
Although the depredation rate in 2016 was more than twice that in 2015, depredation rates in 2016 were similar in to those in 2014 prior to enhancement.

When categorized by treatment area, apparent nest success rates from 2015-16 were $55 \%$ in plot New 1 (47 nests), 27\% in plot New 2 (15 nests), and 38\% in Control (17 nests; Figure 5).

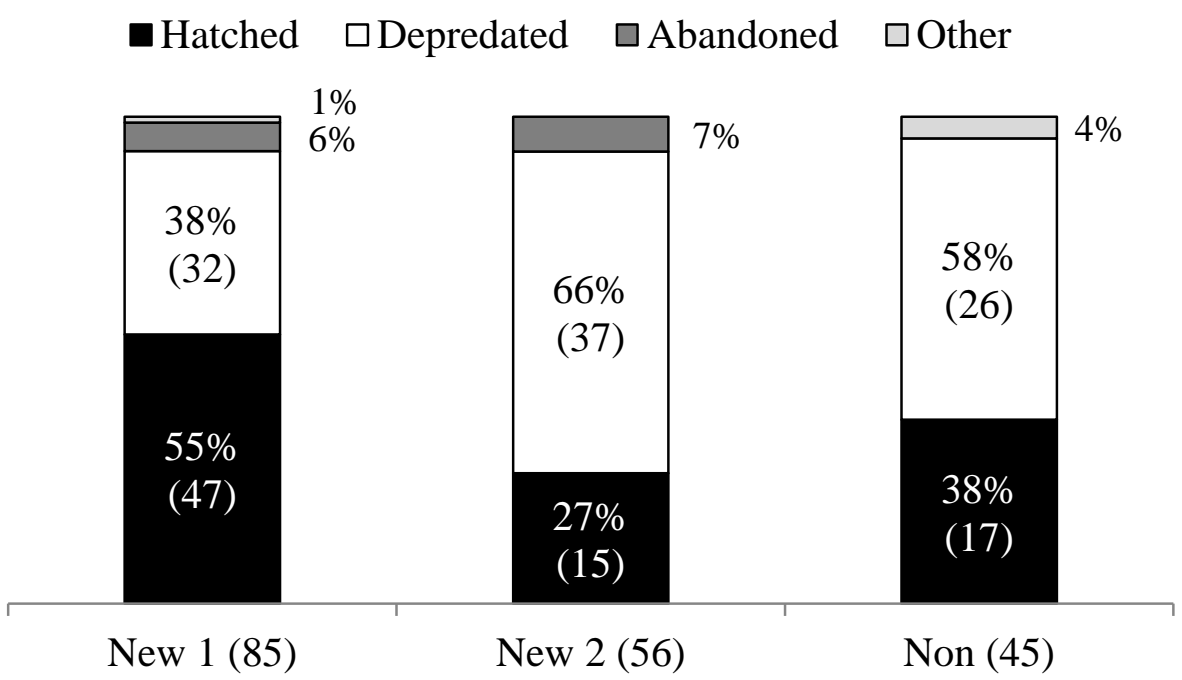

Figure 5. The proportion of plover nests by fate in enhancement treatment plots (New 1 and New 2) and the Control area in pond E14 in Eden Landing Ecological Reserve, Alameda County, California in 2015 and 2016, combined. The number of nests found in each treatment plot, and the number of hatched and depredated nests is shown in parenthesis.

During both individual years and cumulatively, the apparent proportion of hatched nests was highest in plot New 1, and lowest in New 2.

Apparent hatch rates declined in all areas from 2015 to 2016, and by 32-40\% (Figure $6)$. 


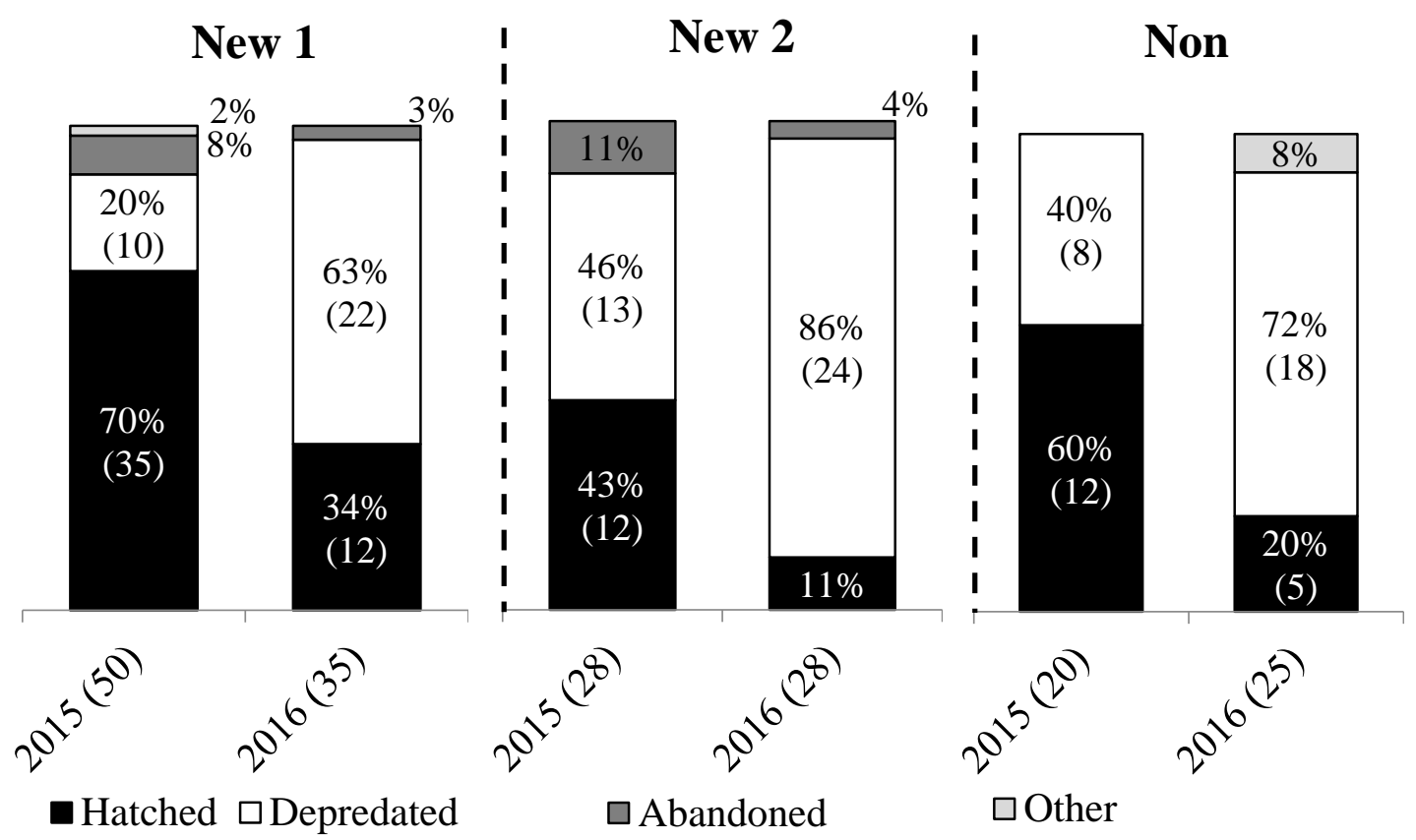

Figure 6. The proportion of plover nests by fate in enhancement treatment plots (New 1, New 2, Control) in pond E14 in Eden Landing Ecological Reserve, Alameda County, California in 2015 and 2016, separately. The number of nests is shown in parenthesis.

Nest abandonment was only detected in treatment plots New 1 and New 2, and rates were higher in 2015 than 2016.

The proportion of nest fates within the three Pilot plots were also examined independently (Figure 7). 


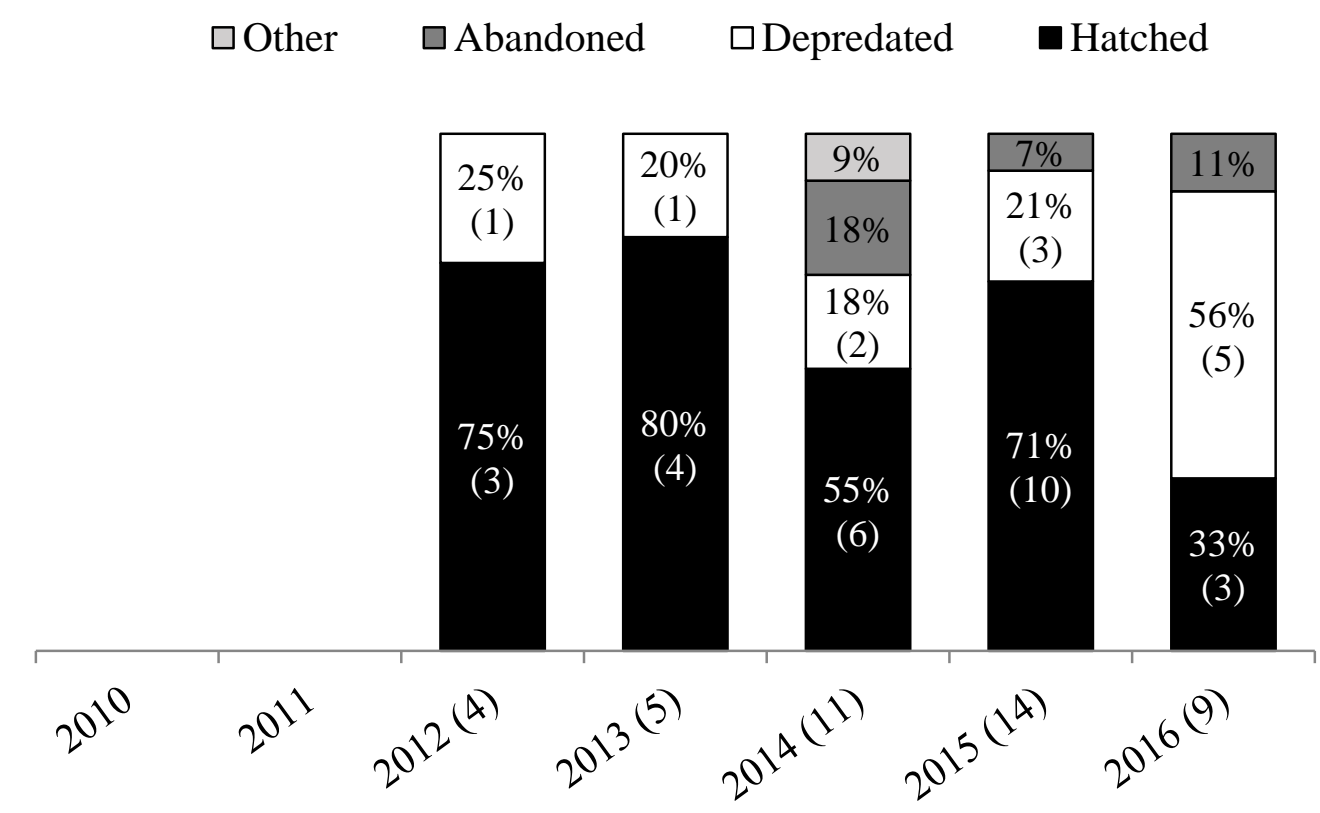

Figure 7. The proportion of plover nest fates in one-hectare pilot study plots in pond E14 in Eden Landing Ecological Reserve, Alameda County, California. The number of nests is shown in parenthesis. Plots were spread in 2008.

Fourteen and nine nests were found in pilot study plots during 2015 and 2016, respectively, and an increase in depredation was seen between 2015 and 2016, as was seen throughout pond E14.

The average weekly apparent plover nest density throughout pond E14 was $0.39 \pm$ 0.18 nests per hectare in 2015 , and $0.30 \pm 0.17$ nests per hectare in 2016. Categorized by treatment type, average weekly nest density was highest in New 1 during both study years $(1.14 \pm 0.56$ and $0.70 \pm 0.44$ nests per hectare in 2015 and 2016 , respectively; Figure 8). 


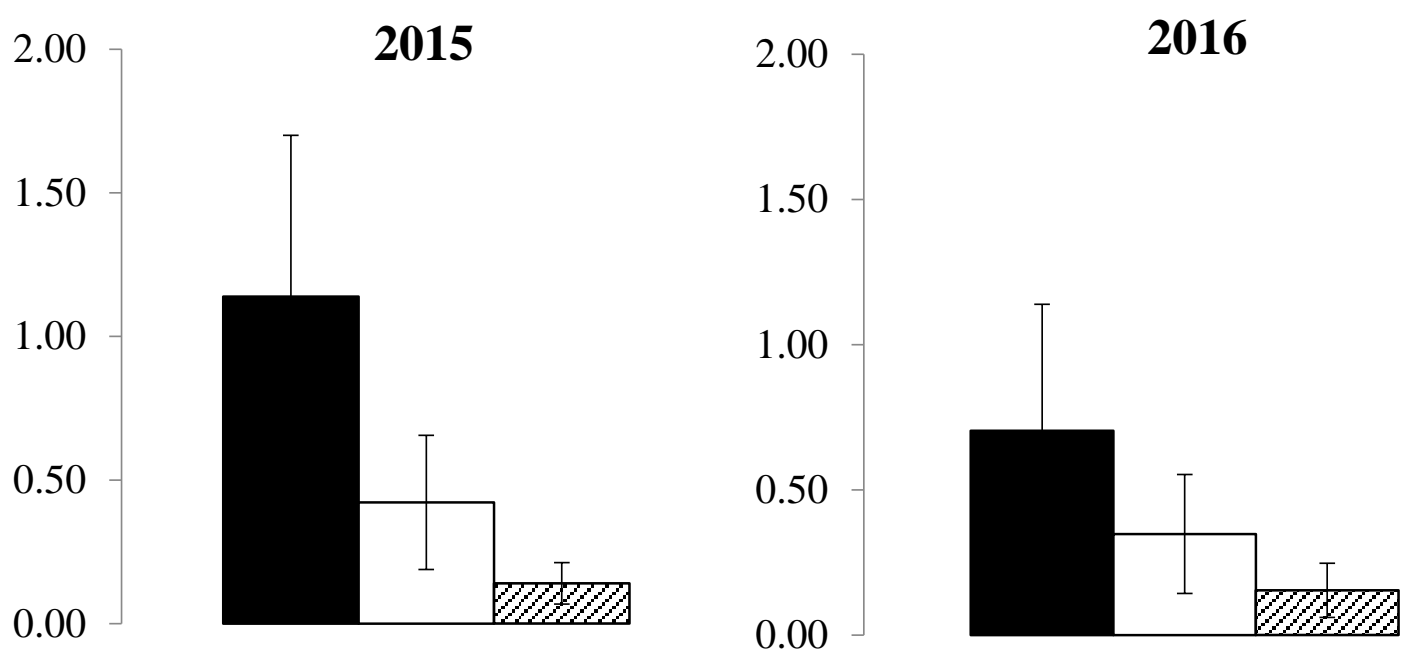

$\square$ New 1 (50) $\square$ New 2 (28) $\square$ Control (20) $\square$ New 1 (35) $\square$ New 2 (28) $\square$ Control (25)

Figure 8. The average weekly nest density (number of nests per area in hectares) in pond E14 in Eden Landing Ecological Reserve, Alameda County, California, from 2015-16. Error bars represent standard error.

The second highest nest density was found in New 2 during both study years; the lowest nest density was consistently found in Control.

The distance to nearest nest neighbor on each nests' $20^{\text {th }}$ day of activity ranged from 9.8 meters to $1,042.7$ meters from 2015 to 2016 ; the average distance was $87.4 \pm 112.6$. Average distances were shortest in New 1 in 2015 (65.7 \pm 41.8 meters), and in New 2 in $2016(95.6 \pm 69.2$ meters $)$.

The chi-square analysis comparing four models of the relationship between nest site selection and the proportion of habitat available showed that the relationship between variables in models 1-3 were significant (Table 1). 
Table 1

Chi-square Analysis of Plover Nest Site Selection

\begin{tabular}{lrrr}
\hline Model & $\mathrm{N}$ & $\chi^{2}$ & $\mathrm{df}$ \\
\hline 1 (New 1+ Pilot, New 2, Control) & 186 & $119.5^{*}$ & 2 \\
2 (New 1 + Pilot, New 2) & 141 & $11.8^{*}$ & 1 \\
3 (New 1, New 2, Control) & 164 & $75.2^{*}$ & 2 \\
4 (New 1, New 2) & 119 & 2.4 & 1 \\
\hline
\end{tabular}

Note. Chi-square analysis results showing nest site selection in pond E14 Eden

Landing Ecological Reserve, Alameda County, California from 2015-16. * $p<.05$.

Among all nesting plovers in E14, preference for nest site was not equally distributed throughout the pond. Plovers selected for New 1 over New 2 when Pilot plots were included and New 2 over Control. The relationship between variables in model 4 was not significant indicating that nesting plovers in E14, excluding those found in Pilot plots, did not prefer New 1 over New 2.

A principal component analysis showed no difference in nest site characteristics for nests with hatched, depredated, or other fates throughout pond E14 (Figure 9). 


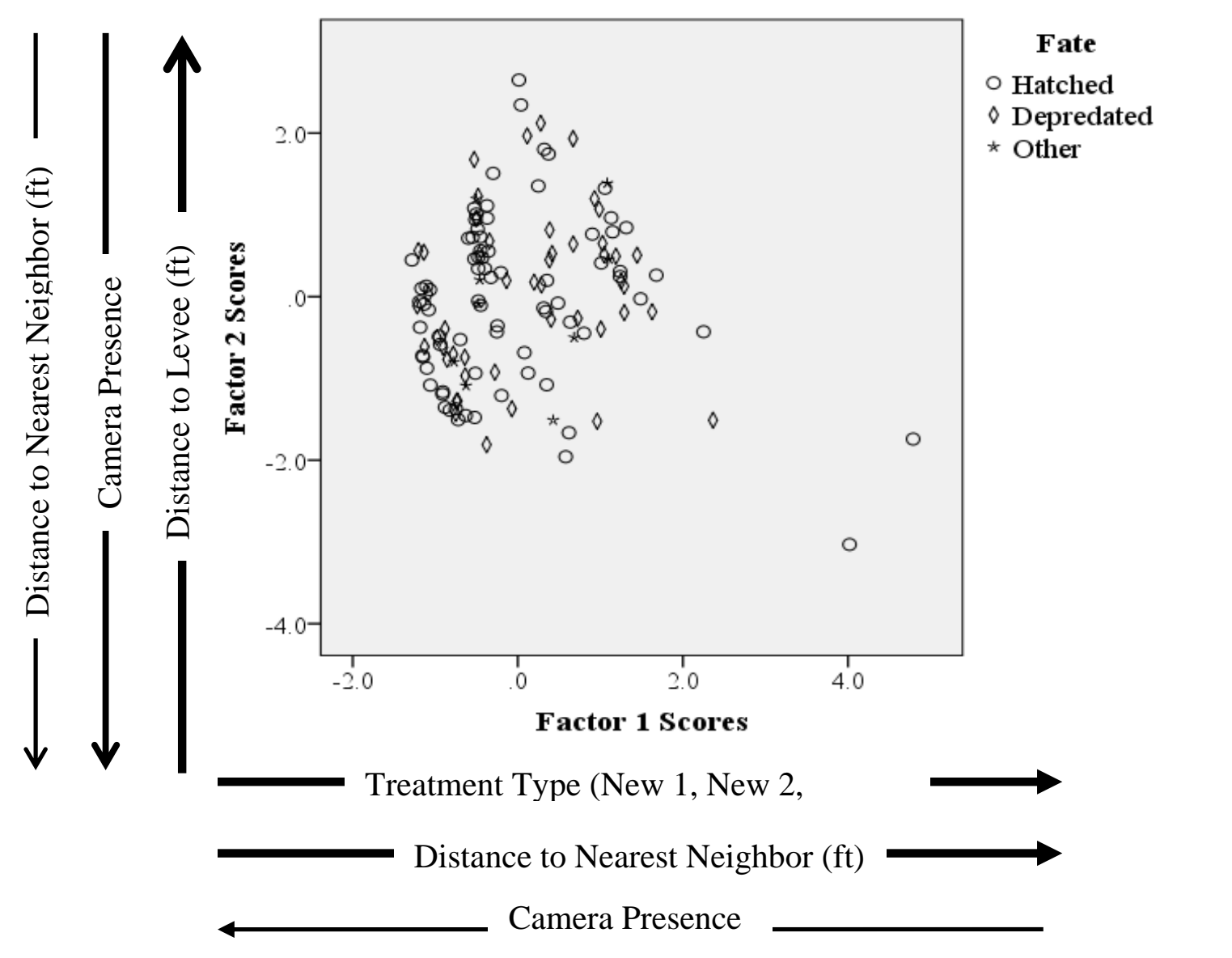

Figure 9. Principal component analysis factor scores characterizing nest sites on each nest's $20^{\text {th }}$ day of activity in pond E14 Eden Landing Ecological Reserve, Alameda County, California, from 2015-16.

Daily nest survival rate (DSR) significantly decreased throughout E14 by time over each season, in New 1 and New 2 by time over each season, and by year throughout E14 (Table 2). 
Table 2

Daily Nest Survival Analysis

\begin{tabular}{|c|c|c|c|c|c|c|c|}
\hline & & & & & & DSR & DSR \\
\hline Model & Parameters & Estimate & $\mathrm{SE}$ & Lcl & $\mathrm{Ucl}$ & Day 1 & Day 182 \\
\hline Dot & & 0.9527 & 0.0048 & 0.9422 & 0.9613 & & \\
\hline Time* & & -0.0117 & 0.0032 & -0.0179 & -0.0055 & & \\
\hline Nest Age & & 0.0274 & 0.0169 & -0.0057 & 0.0605 & & \\
\hline Camera & & 0.0758 & 0.2149 & -0.3455 & 0.4970 & & \\
\hline \multicolumn{8}{|l|}{ Distance } \\
\hline to Levee & & -0.0022 & 0.0021 & -0.0063 & 0.0019 & & \\
\hline \multirow[t]{3}{*}{ Year* } & & -1.2548 & 0.2208 & -1.6877 & -0.8220 & & \\
\hline & $2015^{*}$ & 0.9741 & 0.0045 & 0.9637 & 0.9815 & & \\
\hline & $2016 *$ & 0.9115 & 0.0111 & 0.8872 & 0.9310 & & \\
\hline
\end{tabular}

Time by

Treatment

$\begin{array}{lrrrrrr}\text { Time } \times \text { New 1* } & -0.0201 & 0.0079 & -0.0356 & -0.0045 & 0.995 & 0.834 \\ \text { TimexNew 2* } & -0.0186 & 0.0082 & -0.0346 & -0.0026 & 0.986 & 0.710 \\ \text { TimexControl* } & 0.0180 & 0.0069 & 0.0046 & 0.0315 & 0.946 & 0.947\end{array}$

Note. Daily nest survival (DSR) model outputs for all plover nests in pond E14 in Eden Landing Ecological Reserve, Alameda County, California from 2015 to 2016.

Confidence intervals containing zero are not significant; negative intervals indicate a decrease in survival; positive intervals indicate an increase in survival. * indicates significance based on $\mathrm{Lcl}$ and Ucl values.

DSR did not significantly vary by habitat types independent of time (New 1, New 2, Control), by nest age, distance to nearest levee, or camera presence. The distance to nearest levee was nearly significant for survival. From 2015-16, nest survival models showed a constant DSR of 95\% throughout pond E14 (Table 2). As a result, each nest had a $20 \%$ probability of surviving for 33 days to successfully hatch. DSR throughout 
pond E14 decreased by $10 \%$ over the course of each season; DSRs on the first day of each season declined from 97\% in 2015 to $91 \%$ in 2016.

Examining survival by treatment type from 2015 to 2016 shows that DSR declined from $99.5 \%$ to $83.3 \%$ in New 1, and from $98.6 \%$ to $71 \%$ in New 2 between 2015-2016 (Figure 10 and 11).

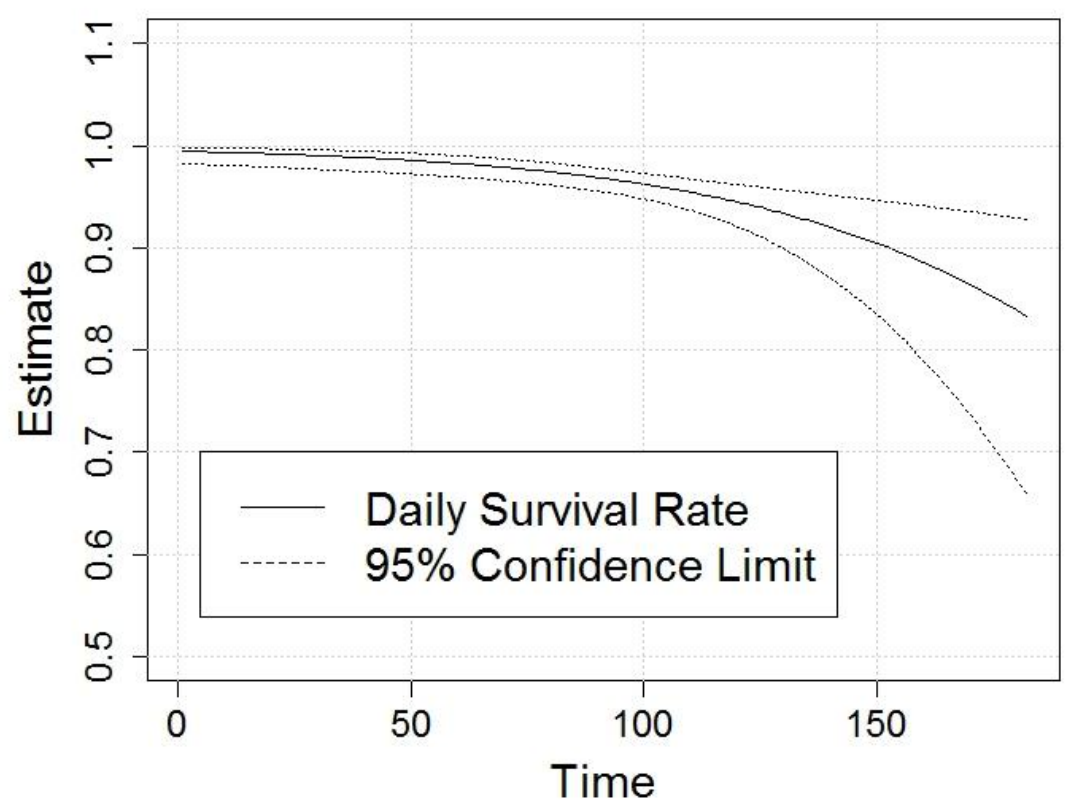

Figure 10. Daily nest survival rates of nests within treatment plot New 1 as affected by time (days over season), in pond E14 from 2015 to 2016. Estimate represents DSR. 


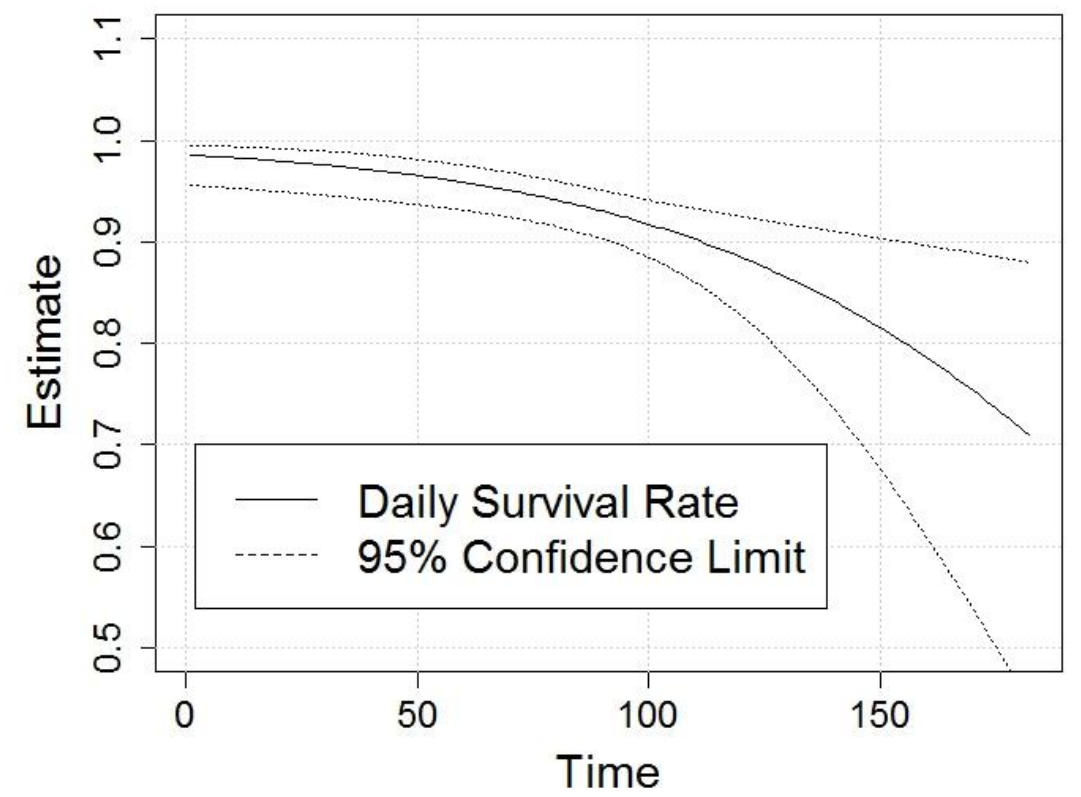

Figure 11. Daily nest survival rates of nests within treatment plot New 2 as affected by time (days over season), in pond E14 from 2015 to 2016. Estimate represents DSR.

DSR remained constant at $94.7 \%$ in Control (Figure 12).

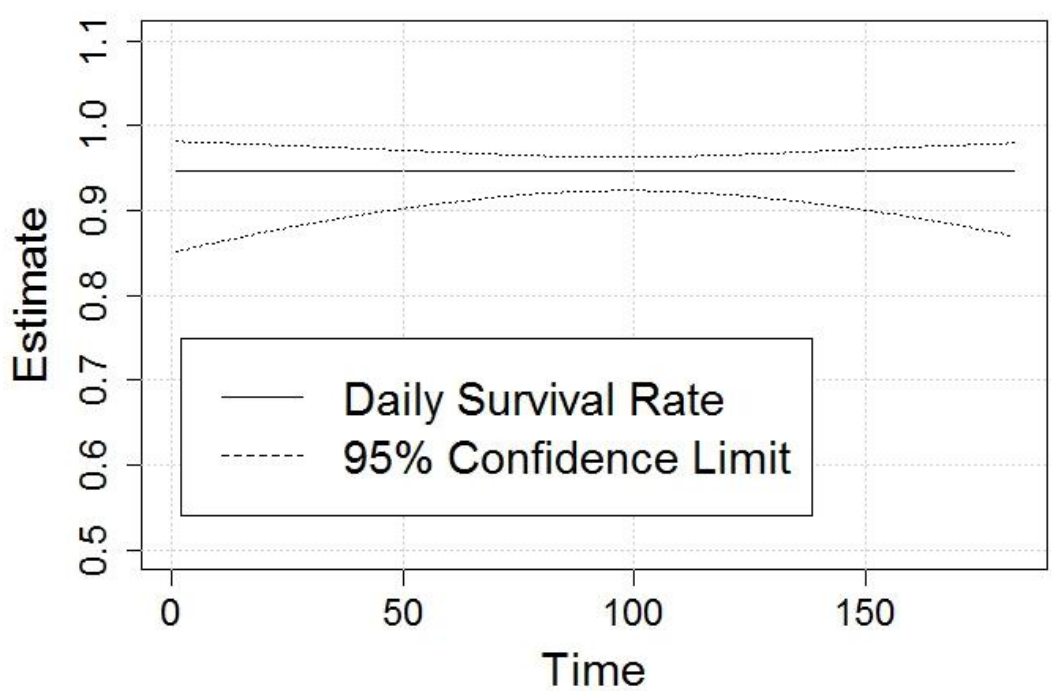

Figure 12. Daily nest survival rates of nests within Control plot as affected by time (days over season), in pond E14 from 2015 to 2016. Estimate represents DSR. 
Time and each treatment type were treated as interactions within the model rather than independent parameters.

The following avian predator species were observed in and around pond E14: American kestrel (Falco sparverius), burrowing owl (Athene cunicularia), Cooper's hawk (Accipiter cooperii), merlin (F. columbarius), northern harrier (Circus cyaneus), peregrine falcon (F. peregrines), red-tailed hawk (Buteo jamaicensis), California gull (Larus californicus), American crow (Corvus brachyrhynchos), common raven $(C$. corax), great blue heron (Ardea herodias), great egrets (A. alba), snowy egret (Egretta thula), and loggerhead shrike (Lanius ludovicianus). Common mammalian predators observed included grey fox (Urocyon cinereoargenteus) and red fox (Vulpes vulpes).

From 2015-16, nest cameras were placed on 97 nests of which 53 were depredated. Predator species of 41 nests were confirmed from camera footage. Common raven (raven) depredated 40 nests (eggs) while peregrine falcon (falcon) depredated recently hatched chicks of one nest. Eleven nests were depredated by CORA in New 1, 15 in New 2, nine in Control, and five in Pilot plots.

A peregrine falcon nest was found in a hunting blind in an adjacent pond within 200 meters of enhancement plot New 1 in 2015, and produced two fledglings in early June of 2015. Adult and fledgling falcons were consistently seen perched within and hunting over pond E14 in 2015. Researchers observed that a plover chick and adult were also depredated by an adult falcon on two separate occasions. 


\section{Brood Results}

A sample of 85 chicks and 26 adult plovers were banded in pond E14 from 2015 to 2016. Thirty-seven banded chicks were confirmed fledged resulting in an apparent fledge success rate of 43\%. Rates were $44 \%$ in 2015 and $42 \%$ in 2016.

A total of 217 broods were monitored over the course of this study. A multiple proportions test was used to analyze the relationship between the proportions of brood behaviors in all treatment types.

Broods were just as likely to be found foraging New 1 compared to New 2, suggesting no selection of a specific treatment type to forage. Broods were nearly likely to be found foraging in all New areas compared to Control (Table 3).

Table 3

Chi-square Analysis of Brood Behavior

\begin{tabular}{lrrr}
\hline Model & N & $\chi^{2}$ & df \\
\hline 1 (New 1*New 2) & 73 & $7.9^{*}$ & 3 \\
2 (New1+2*Control) & 186 & 7.4 & 3 \\
\hline
\end{tabular}

Note. Chi-square analysis results showing behavior site selection in pond E14 Eden Landing Ecological Reserve, Alameda County, California from 2015-16. *p <.05.

\section{Discussion}

This study was designed to assess the efficacy of oyster shell enhancement of dry salt pond habitat in promoting western snowy plover breeding success. I found that large scale oyster shell enhancement attracted greater densities of breeding plovers than nonenhanced areas. This effect has been observed for western snowy plovers and California 
least terns in coastal beach habitat (Pearson et al., 2009; Zarnetske et al., 2010) and in artificial or salt panne habitat (CDFW, 2011; Riensche et al., 2015).

Nest numbers within pond E14 nearly doubled immediately after enhancement compared to pre-enhancement years (Tokatlian et al., 2014). This was seen during both study seasons (98 in 2015 and 88 in 2016) compared to those immediately prior to enhancement (54 in 2014 and 33 in 2013). From 2008-2014, approximately 200 hectares of neighboring ponds that had previously supported breeding plovers were converted from dry pond habitat to tidal action, and it is possible that plovers elected to breed in pond E14 in response to this loss of historical habitat. However, suitable habitat remained available in other neighboring ponds during 2015 and 2016 where few plovers were found. Thus, it seems likely that large scale oyster shell enhancement in pond E14 attracted breeding plovers.

In addition, I found that plovers preferred treatment plot New 1 over New 2. Interestingly, when nests in older Pilot plots were removed from this analysis, nest site selection did not significantly differ between New 1 and New 2. It appears that plover selection of New 1 was contingent on the presence of older study plots from 2008, suggesting that older enhancement areas may have a lasting and positive effect on nest site selection. Plovers are naturally philopatric, often returning to the same natal grounds to breed (Colwell et al., 2007; Stenzel et al., 2007). This behavior, in combination with the seemingly attractive quality of enhancement plots, may be important factors in these lasting effects. 
Plovers did nest in one-hectare Pilot plots in Eden Landing ponds E16B and E8 immediately after their enhancement (Robinson-Nilsen \& Demers, 2010). SFBBO biologists observed the highest known plover nest density of the San Francisco Bay in one of the pond E8 plots in 2010 (9 nests/hectare concurrently active); two of the pond E16B plots were also used heavily. This report mirrors the pattern of high plover nesting density immediately after enhancement at pond E14 in 2015 and 2016.

However, oyster shell enhancement did not appear to have a substantial effect on apparent nest fate in pond E14, nor did it have a statistically significant effect on daily nest survival rates. When examining all oyster shelled areas together, descriptive analysis suggests that plover nests were more successful there compared to non-enhanced habitat, as hypothesized based on Dinsmore et al., (2014). However, nest success rates were only higher than Control in New 1, revealing an inconsistency between the effects of New 1 and New 2. There were no substantial differences in size, treatment density, or shell quality between New 1 and New 2. New 1 was within 300 meters of a perimeter water channel which provided healthy foraging habitat (Figure 2). New 2 was within 400 meters of this channel, as well as an often saturated panne in the northeast corner which also provided healthy foraging habitat.

It is not clear whether distance to water or foraging habitat was a significant factor in nest site selection for this study. During nest incubation, an adult plover remains at the nest site during each 12-hour shift while the alternate adult forages and roosts nearby (Page et al., 2009). Nests in similar alkaline flat habitat averaged 379 to 425 meters from a water source (Ruhlen et al., 2006). The presence of the Pilot plots near New 1 was one 
notable dissimilarity; however nest fates in Pilot plots showed similar trends as those in New 1 and therefore suggest little effect on overall success.

Nests were less likely to survive a single day in the later portion of each season, though this trend was only seen in enhancement plots New 1 and New 2, while daily survival rates remained constant over the course of each season in Control. Common raven predation was the primary cause of nest failure, rather than abandonment or egg infertility. These results indicate that pond E14 was incidentally within a raven feeding territory, or that raven individuals recognized the enhancement plots over time as a reliable food source. Oyster shell enhancement may not effectively improve plover nesting success without concurrent predator management.

Predation impacts were substantially higher at both enhanced and control sites in 2014 and 2016 compared to 2015. From nest camera data, I found that ravens were responsible for all but one documented nest depredation in 2015 and 2016. Predation impacts were substantially higher at both enhanced and control sites in 2014 and 2016 compared to 2015 .

Raven populations in the Western United States have increased by $166 \%$ over the last 40 years (BirdLife International, 2016). This trend is mirrored in raven populations within the San Francisco Bay, and with greater densities near urbanized areas and along the outer coast compared to rural areas (Kelly et al., 2002). Personal communication and historical data show that ravens established near East Bay salt ponds by 1980, and numbers have continued to grow (Butcher, 1990; Sauer et al., 2001). Ravens are highly intelligent and are prevalent near urban habitats, benefiting from trash, crops, and other 
continuous anthropogenic sources (Harding et al., 1998; Jiménez \& Conover, 2001; Meckstroth \& Miles, 2005). Ravens are less gregarious than other corvid species and are typically found alone, or in pairs (Boarman \& Heinrich, 1999). Breeding ravens occupy the same territory to feed, mate, and nest year-round (Webb et al., 2012).

In Marin County, California, breeding raven home-range size and space use were found to be directly related to the distribution of food sources; foraging distances from the nest were statistically shorter during incubating and nestling stages (Roth et al., 2004). Raven nests were within 3.7 kilometers of an anthropogenic (parking lot, dumpster) or natural (shorebird colony) food source, aligning with previous research which found a relationship between food distribution and home-range size (Marzluff et al., 1994). In Poland, Rösner and Selva (2005) determined the territory size of breeding ravens at $13.1 \mathrm{~km}^{2}$. Based on camera evidence and predation rates from this study, it is likely that a pair nested near pond E14 and regularly foraged the dense nesting plover colony within it. It is unclear whether oyster shell enhancement attracted ravens to the site.

Common ravens have had substantial impacts on breeding shorebird colonies (Kelly et al., 2002; Marzluff et al., 1994; Perry \& Henry, 2010) due to their relentless and intelligent foraging behavior, often returning to the colony several times, and effectively removing the majority of nests. This raises the concern that nesting plovers will be more susceptible to failure if a highly intelligent species (ie. corvid) identifies breeding colonies as plover habitat decreases and nesting density increases. More concerted and 
concurrent predator management will be vital for the success of these areas, and for reaching population recovery goals (Page et al., 1999U; SFWS, 2007).

Nest camera footage often showed two individual ravens during a depredation event which suggests that a pair was regularly visiting and scavenging the site. Footage showed that a raven would typically arrive at a plover nest and eat the eggs individually, either by swallowing them entirely or pecking out the contents with its bill. Common raven depredation events lasted between 2-15 minutes; one predation event occurred just 30 minutes after a biologist had visited the nest. On several occasions, the raven walked out of the camera frame while carrying a plover egg, possibly to eat or cache elsewhere.

A similar study used nest cameras to document plover nest predation events in Eden Landing Ecological Reserve in 2009 and 2010 (Demers \& Robinson-Nilsen, 2012; Robinson-Nilsen \& Demers, 2010); several predators were documented. A total of 44 plover nests were filmed in Eden Landing ponds during their study, identifying the following species: California gull (3 events), gray fox (1 event), ruddy turnstone (1 event; Arenaria interpres), northern harrier (2 events), red-tailed hawk (2 events), and common raven (1 event). Based on Robinson-Nilsen's (2010) results, it would be reasonable to expect a number of these species to have depredated plover nests in pond E14 in 2015 and 2016.

The fact that common raven was effectively the only documented species in E14 from 2015-2016 further suggests that a pair had successfully established and defended a feeding territory there. The nesting peregrine falcon pair may have kept ravens at bay during 2015, as falcons were often seen flying over and perched within the pond. Further 
research is needed to understand the relationships between predator species and their territories, and to determine whether ravens keyed in on the oyster shells themselves as a potentially fruitful foraging location.

All of these scenarios demonstrate the need for intensive and targeted predator management in order to increase plover nesting success. In addition, further study of the impacts of predation on breeding plovers is needed to effectively manage this population, particularly in an urban influenced environment where natural predator-prey dynamics have been altered (Jokimäki \& Huhta, 2000).

I could not distinguish chick fledging rates between enhanced and control sites; therefore rates should be interpreted with caution. Only a small sample of chicks were banded due to the large amount of effort required to capture chicks before leaving the nest site, and to high nest depredation rates in 2016. Accurately resighting small color band combinations in large expanses of habitat is extremely challenging. Furthermore, broods immigrate to and emigrate from nearby ponds, and may not be detected by biologists after hatching. Adult males incubating nests were banded whenever possible. Adult males remain with their chicks until fledged, therefore theoretically detecting a solitary male for an extended period of time indicated that its chicks did not survive. Minimal data were collected on solitary banded males during this study.

Plover population viability is dependent on a number of factors including adult survivorship, numbers of nests, nesting success, and fledgling success (USFWS, 2007). While it is important to quantify plover nesting success, it is not entirely clear how this parameter correlates to fledgling success and population viability (Dinsmore et al., 2014). 
Fledgling success is not well understood in the San Francisco Bay and this parameter requires more investigation. Current methods of quantifying fledgling success through band-resighting are logistically challenging in pond habitat and were not entirely reliable in this study.

Oyster shell enhancement did not appear to strongly influence where broods selected to brood, forage, or roost. Anecdotal evidence from brood surveys suggests that brood location and behavior were largely determined by the location of water, or saturated ground, where invertebrate prey was plentiful. This information is logical and valuable for resource management, as maintaining adequate foraging habitat within ponds is essential to support developing plover chicks regardless of habitat enhancement.

While greater nesting activity and densities can benefit the population by boosting breeding numbers, this pattern in plots New 1 and New 2 may have contributed to nest abandonment in 2015. Plover nest territories are typically $<0.5$ hectares in size in salt panne habitat (Warriner et al., 1986). Powell and Collier (2000) found that nest density at a southern Californian dredged restoration site ranged from 0.5-3.2 and 1.3-1.7 nests per hectare over a period of five years. Nesting territories in Utah were smaller with an average distance to nearest neighbor of 14.5 hectares (Paton, 1994) and 80-46 hectares in two Great Plains colonies (Boyd, 1972; Grover \& Knopf ,1982). Although the nearest neighbor distances and nesting densities of plovers in this study are similar, plovers in the South Bay have not historically nested in densities as high as what was found in New 1 (Pearl et al., 2015). Perhaps this change in breeding conditions sparked more aggressive territoriality in breeding plovers, resulting in higher stress and abandonment levels. 
Aggression between breeding plover adults and broods may increase due to higher nesting densities as territories are encroached (Page et al., 2009), and as broods move throughout dense colonies in search of foraging habitat. Intraspecific aggression between plover adults and broods was anecdotally documented during this study more often than in years prior to enhancement. This must be considered if oyster shell enhancement is used as a method to increase plover breeding activity, as aggression will negatively impact overall breeding success. The overall impact of oyster shell enhancement may be negligible if it encourages breeding activity while simultaneously increasing nest abandonment, aggression, or chick mortality.

The western snowy plover species recovery plan cites habitat loss due to climate change and sea-level rise as a substantial threat to population recovery (USFWS, 2007). The Tidal Marsh Recovery Plan anticipates sea-level rise along California's coast by 1.01.4 meters, and possibly as high as 2.0 meters by the year 2100 under extreme scenarios (Heberger et al., 2009; USFWS, 2013). A recent range-wide PVA for plovers (Hudgens et al., 2014) has shown that, due to dispersal of individuals from the Bay Area, reproductive success and survival in South Bay salt ponds has a large impact on the abundance and recovery of the range-wide population. Therefore, as coastal plover habitat will be more quickly impacted by sea-level rise, supporting levee-protected managed pond habitat in the San Francisco Bay will be increasingly important for stabilizing the range-wide population. 


\section{Conclusions}

This study indicates that oyster shells can be strategically applied to areas where plovers should be encouraged to nest in the South Bay, to potentially offset the effect of habitat loss due to tidal restoration, or to encourage individuals to breed in officially designated plover habitats (Department of the Interior, 2012). Study results may assist resource managers in achieving multiple species goals with contrasting ecological requirements during further project actions.

However, it is not likely that enhancement will improve plover nesting success without concurrent and substantial predator management. It is necessary to understand if predators are keying in on enhanced areas or if this effect is more opportunistic. Evaluating the relationship between predators and habitat enhancement in essential for determining the efficacy of this method in order to improve plover breeding success; is counterproductive to the original motivation if enhancement attracts both plovers and predators to an area. Further research is also needed to assess plovers' ability to persist in a changing climate, to better quantify fledgling survival rates, and design effective predator control methods.

A nesting density limit may eventually be reached for plovers breeding in enhanced areas, and as plover habitat is reduced during future project phases. Researchers may be able to quantify this limit by continuing to study the multi-year effect of enhancement on nesting activity in pond E14. This metric will be valuable as it will define the minimum amount of habitat required to support project and species recovery goals (250 and 500 breeding individuals, respectively). Brood behavior was not strongly affected by 
enhancement. Instead, behavior and habitat preference appeared to be influenced by prey availability near water sources.

Enhancement should not be applied further without fully understanding temporal variation in predator dynamics, and the relationship between predation and oyster shells. Otherwise, the species' delicate source-sink balance across the Pacific coast range may be disrupted. The San Francisco Bay plover population is currently stable, but if well intentioned actions are taken without a complete understanding of their outcomes, the population may be pushed toward a sink which may ultimately affect rangewide stability.

\section{Recommendations}

Multi-year effects of large scale oyster shell enhancement in pond E14 should continue to be investigated. It is clear that nesting success can change drastically between and within breeding seasons due to predation pressure, or perhaps external factors that were not addressed in this research. Furthermore, enhanced areas were shown to attract breeding plovers over multiple seasons, and quantifying the duration of this effect will allow resource managers to apply cost effective enhancement strategies. Future project phases may strategically implement this strategy to attract breeding plovers to specific ponds which may alleviate the need for expansive tracts of habitat managed for a single species.

Detailed patterns and impacts of predation should be investigated on breeding plovers in both enhanced and non-enhanced areas. Common raven populations and pairs in the South Bay must be controlled in order to achieve plover recovery; methods may include removal, relocation, or behavioral influence (perhaps through egg taste aversion or 
effigies), however, studies reveal substantial caveats for each of these methods (Gabriel \& Golightly, 2014; Velasco, 2015). These possibilities should be investigated further. Peregrine falcons and other predators that utilize structures should be discouraged from nesting near plover breeding sites when possible to reduce impacts to nesting shorebirds.

Predation impacts may also be reduced by removing structures that can be used as perches, both within and surrounding plover breeding sites. Nests of predatory species should continue to be removed from power towers, hunting blinds, nearby levees and trees.

Land managers should encourage healthy foraging habitats by maintaining water in both perimeter and internal channels of ponds. This will also decrease intraspecific resource competition and potential aggression between family groups. However, pond bottom pannes where oyster shell enhancement plots have been spread should be infrequently flooded during the off-season to avoid weathering shells with mud and silt. Once dirtied, oyster shells lose camouflaging qualities and may become less effective for attracting breeding plovers and for improving breeding success.

Oyster shells used in this study were donated and purchased from Drake's Bay Oyster Company, Marin County, who retained a surplus of shells post canning process. The company is no longer in business and can no longer provide oyster shells. Current potential sources of oyster shell are not in close proximity (out of state), or would require substantial effort and resources to collect and clean (from restaurants). A similar and more cost effective material for habitat enhancement, such as medium sized commercial grade gravel, should be explored and studied. 
Developing an improved method for estimating plover fledge success will provide a more accurate measure of recruitment in the San Francisco Bay. Small GPS tracking technologies are becoming increasingly affordable, and they can be used to better quantify chick survival and movement (Chan et al., 2016). Statistical methods (Zipkin et al., 2014) that require observational data from both marked and unmarked individuals may also be beneficial.

Finally, identifying and managing new plover breeding areas outside of the project footprint may improve the odds of reaching species recovery goals in the South Bay, and ultimately throughout the Pacific coast range. The majority of South Bay plover breeding habitat is found within the project footprint in former salt ponds, and the project's ultimate goal is to restore up to 6,110 hectares back to tidal marsh. In the absence of habitat enhancement or predator control, achieving both project and federal species recovery goals may ultimately depend on finding alternative breeding habitat. 


\section{References}

Accurso, L. M. (1992). Distribution and abundance of wintering waterfowl on San Francisco bay 1988-1990. Unpublished master's thesis, Humboldt State University, Arcata, California.

Ackerman, J. T., Takekawa, J. Y., Strong, C., Athearn, N., \& Rex, A. (2006). California gull distribution, abundance, and predation on waterbird eggs and chicks in South San Francisco bay. U.S. Geological Survey. Unpublished report.

Ackerman, J. T., Herzog, M. P., Herring, G., Hartman, C. A., Bluso-Demers, J., \& Robinson-Nilsen, C. (2013). Impact of salt pond restoration on California gull displacement and predation on breeding waterbirds. Unpublished report.

American Birding Association. (1957). The A.O.U. checklist of North American birds. Fifth edition. American Ornithologists Union.

Andren, H. (1994). Effects of habitat fragmentation on birds and mammals in landscapes with different proportions of suitable habitat: A review. Oikos, 71(3), 355-366.

Battin, J. (2004). When good animals love bad habitats: Ecological traps and the conservation of animal populations. Conservation Biology, 18(6), 1482-1491.

Best, L. B. (1986). Conservation tillage: Ecological traps for nesting birds? Wildlife Society Bulletin, 14, 308-317.

Benitez-Lopez, A., Alkemade, R., \& Verweij. P. A. (2010). The impacts of roads and other infrastructure on mammal and bird populations: A meta-analysis. Biological Conservation, 143(6), 1307-1316.

BirdLife International. (2016). The IUCN Red List of Threatened Species 2016: e.T22706068A87396663. http://dx.doi.org/10.2305/IUCN.UK.20171.RLTS.T22706068A113271893.en. Downloaded on 12 March 2017.

Blair, R. B. (1996). Land use and avian species diversity along an urban gradient. Ecological Applications, 6, 506-519.

Boarman, W. I., \& Berry, K. H. (1995). Common ravens in the southwestern United States, 1968-92. In E. T. Laroe (Ed.), Our living resources: a report to the nation on the distribution, abundance, and health of U.S. plants, animals, and ecosystems (pp. 73-75). Washington D.C.: USDI National Biological Service. 
Boarman, W. I., \& Bernd Heinrich. (1999). Common Raven (Corvus corax). The Birds of North America, No. 476 (A. Poole, Ed.). The Birds of North America Online, Ithaca, New York.

Boyd, R. L. (1972). Breeding biology of the snowy plover at Cheyenne Bottoms Waterfowl Management Area, Barton County, Kansas. Unpublished master's thesis, Emporia State University, Emporia, KS.

Brown, A. K. (1960). Salt for the Scraping: Origin of the San Francisco Bay salt industry. California Historical Society Quarterly, 39(2), 117-120.

Brusca, R. C., \& Brusca, G. J. (2003). Invertebrates. $2^{\text {nd }}$ edition. Sunderland MA: Sinauer Assoc.

Burgess, R. L., \& Sharpe, D. M. (1981). Forest island dynamics in man-dominated landscapes. New York: Springer.

Butcher, G. S. (1990). Audubon Christmas bird counts, in survey designs and statistical methods for the estimation of avian population trends (J. R. Sauer and S. Droege, eds.). U.S. Fish and Wildlife Service. Unpublished report.

Butcher, G. S., \& Niven, D. K. (2007). Combining data from the Christmas bird count and the breeding bird survey to determine the continental status and trends of Ruhlen, T., G. Page, L. Stenzel. (2006) Effects of a changing environment on nesting Snowy plovers at Owens Lake, California. Western Birds, 37 (2006), 126-138

California Department of Fish and Wildlife. (2011). Cape Mohican restoration projects annual report January 2011. Unpublished report.

Chace, J. F., \& Walsh, J. J. (2006). Urban effects on native avifauna: a review. Landscape and Urban Planning, 74(1), 46-69.

Chan, Y., Brugge, M., Tibbitts, T., Dekinga, A., Porter, R., Klaassen, R., \& Piersma, T. (2016). Testing an attachment method for solar-powered tracking devices on longdistance migrating shorebird. Journal of Ornithology, 157 (1), 277-287.

Cohen, A., \& Carlton, J. (1998). Accelerating invasion rate in a highly invaded estuary. Science, 279, 555-558.

Cohen, J. B., Houghton, L. M., \& Fraser, J. D. (2007). Nesting density and reproductive success of piping plovers in response to storm- and human-created habitat changes. Wildlife Monographs, 173, 1-24. 
Colwell, M. A., McAllister, S. E., Millett, C. B., Transou, A. N., Mullin, S. M., Nelson, . . LeValley, R. R. (2007). Philopatry and natal dispersal of the western snowy plover. The Wilson Journal of Ornithology, 119 (3): 378-385.

Colwell, M. A., Pearson, W. J., Eberhart-Phillips, L. J., \& Dinsmore, S. J. (2013). Apparent survival of snowy plovers (Charadrius nivosus) varies with reproductive effort and year and between sexes. The Auk, 130(4), 725-732.

Czech, B., \& Krausman, P. R. (1997). Distribution and causation of species endangerment in the United States. Science, 227, 1116-1117.

Dasmann, R. F. (1968). A different kind of country. New York, NY: Collier Books.

Demers, S. A., \& Robinson-Nilsen, C. W. (2012). Monitoring western snowy plover nests with remote surveillance systems in San Francisco Bay, California. Journal of Fish and Wildlife Management, 3, 123-132

Department of the Interior, Fish and Wildlife Service. (2012). Endangered and threatened wildlife and plants; revised designation of critical habitat for the Pacific coast population of the western snowy plover; final rule. Federal Register, 77, 118.

Dias, P. C. (1996). Sources and sinks in population biology. Trends in Ecology and Evolution, 11(8), 326-330.

Diamond, J. M. (2005). Collapse: How societies choose to fail or succeed. London, England: Penguin Books Ltd.

Dinsmore, S. J., Lauten, D. J., Castelein, K. A., Gaines, E. P., \& Stern, M. A. (2014). Predator exclosures, predator removal, and habitat improvement increase nest success of snowy plovers in Oregon, USA. The Condor: Ornithological Applications, 116, 619-628.

Dwernychuk, L. W., \& Boag, D. A. (1972). Ducks nesting in association with gulls - An ecological trap? Canadian Journal of Zoology, 50(5), 559-563.

Emlen, J. T. (1974). An urban bird community in Tucson, Arizona: Derivation, structure, regulation. Condor, 76, 184-197.

Foster, R. B. (1980). Heterogeneity and disturbance in tropical vegetation. In M. E. Soule, \& B. A. Wilcox (Eds.), Conservation biology. An evolutionary-ecological perspective (pp. 75-92). Sunderland, MA: Sinauer.

Funk, W. C., Mullins, T. D., \& Haig, S. M. (2007). Conservation genetics of snowy plovers (Charadrius alexandrinus) in the western hemisphere: Population genetic 
structure and delineation of subspecies. U. S.Geological Survey Staff -- Published Research. Paper 656.

Gabriel, P., \& Golightly, R. (2014). Aversive conditioning of Steller's jays to improve marbled murrelet nest survival. The Journal of Wildlife Management, 78(5), 894-903.

Gratto-Trevor, C. L. (2004). The North American banders' manual for banding shorebirds (Charadriiformes, suborder Charadrii). The North American Banding Council, California.

Gregory, R. (2006). Birds as biodiversity indicators for Europe. Significance, 3(3), 98144.

Grinnell, J., Bryant, H. D., \& Storer, T. I. (1918). The game birds of California. Berkeley, California: Berkeley, University of California Press.

Grover, P. B., \& Knopf, F. L. (1982). Habitat requirements and breeding success of charadriiform birds nesting at Salt Plains National Refuge, Oklahoma. Journal of Field Ornithology, 53,139-148.

Gustafson, M. E., Hildenbrand, J., \& Metras, L. (1997). The North American bird banding manual (Electronic Version). Version 1.0

Haddad, N., Brudvig, L., Clobert, J., Davies, K., Gonzalez, A., Holt, R., . . Townshend, J. (2015). Habitat fragmentation and its lasting impact on Earth's ecosystems. Science Advances, (1). doi: 10.1126/sciadv.1500052

Hansson, L. (1997). The relationship between patchiness and biodiversity in terrestrial systems. In S. T. A. Picket, R. S. Osterfeld, M. Shachak, \& G. E. Likens (Eds.), The ecological basis of conservation: heterogeneity, ecosystems, and biodiversity (pp. 146-155). New York: Chapman and Hall.

Harding, E. K., Doak, D. F., Albertson, J., \& Takekawa, J. E. (1998). Predator management in San Francisco bay wetlands: Past trends and future strategies. U.S. Fish and Wildlife Service. Unpublished report.

Harveson, P. M., Lopez, R. R., Silvy, N. J., \& Frank, P. A. (2004). Source-sink dynamics of Florida Key deer on Big Pine Key, Florida. Wildlife Management, 68(4), 909-915.

Hays, H. \& LeCroy, M. (1971). Field criteria for determining incubation stage for the common tern. Wilson Bulletin 83, 425-429. 
Heberger, M., Cooley, H., Herrera, P., Gleick, P., \& Moore, E. (2009). The impacts of sea-level rise on the California coast. A draft paper from the California Climate Change Center. Pacific Institute. Unpublished report.

Hobbs, F., \& Stoops, N. (2002). U.S. Census Bureau, Census 2000 Special Reports, Series CENSR-4, Demographic Trends in the 20th Century. U.S. Government Printing Office, Washington, DC, 2002.

Hobbs, J., Cook, J., \& Crain, P. (2015). Tidal marsh restoration benefits leopard sharks (Triakis semifasciata) in South Bay Salt Pond Restoration Project ponds. Unpublished report.

Hudgens, B., Eberhart-Phillips, L., Stenzel, L., Burns, C., Colwell, M., \& Page, G. (2013). Population viability analysis of the western snowy plover. Institute for Wildlife Studies. Unpublished report.

IUCN. (2016). The IUCN Red List of Threatened Species. Version 2017-1. http://www.iucnredlist.org. Downloaded on 12 March 2017.

Jiménez, J. E. \& Conover, M. R. (2001). Ecological approaches to reduce predation on ground-nesting gamebirds and their nests. Wildlife Society Bulletin, 29, 62-69.

Johansson, O. C., \& Blomqvist, D. (1996). Habitat selection and diet of lapwing (Vanellus vanellus) chicks on coastal farmland in S. W. Sweden. Journal of Applied Ecology, 33, 1030-1040.

Johnstone, C. P., Reina, R. D., \& Lill, A. (2010). Impact of anthropogenic habitat fragmentation on population health of a small, carnivorous marsupial. Journal of Mammalogy, 91(6), 1332-1341.

Jokimäki, J. \& Huhta, E. (2000). Artificial nest predation and abundance of birds along an urban gradient. Condor, 102, 838-847.

Jones, S. G., Gordon, D. H., Phillips, G. M., \& Richardson, B. D. (2005). Avian community response to a golf-course landscape unit gradient. The Wildlife Society Bulletin, 33(2), 422-434.

Kelly, J. P., Etienne, K. L., \& Roth, J. E. (2002). Abundance and distribution of the common raven and American crow in the San Francisco bay area, California. Western Birds, 33, 202-217.

Kershner, E. L., \& Bollinger, E. K. (1996). Reproductive success of grassland birds at east-central Illinois airports. American Midland Naturalist, 136, 358-366. 
Krech, S. (2009). Spirits of the air. Athens, Georgia: University of Georgia Press.

Kupper, C., Augustin, J., Kosztolanyi, A., Figuerola, J., Burke, T., \& Szekely, T. (2009). Kentish versus snowy plover: Phenotypic and genetic analyses of Charadrius alexandrines reveal divergence of Eurasian and American subspecies. Auk, 126, 839852.

Manly, B. F., McDonald, L., Thomas, D., McDonald, T. L., \& Erickson, W. P. (2002). Resource selection by animals: Statistical design and analysis for field studies. Manhattan, New York: Springer Netherlands.

Marzluff, J.M., Boone, R.B. \& Cox, G.W. (1994). Historical changes in populations and perceptions of native pest and bird species in the west. Studies in Avian Biology, 15, 202-220.

Marzluff, J. M., Bowman, R., \& Donnelly, R. (2001). Avian ecology and conservation in an urbanizing world. Norwell, Massachusetts: Kluwer Academic Publishers.

Meckstroth, A. M. \& Miles, K. (2005). Predator removal and nesting waterbird success at San Francisco Bay, California. Waterbirds, 28(2), 250-255.

Mehl, K. R., Drake, K. L., Page, G. W., Sanzenbacher, P. M., Haig, S. M., \& Thompson, J. E. (2003). Capture of breeding and wintering shorebirds with leg-hold noose-mats. US Geological Survey. Unpublished report.

Mofras, E. D. (1844). Exploration du territoire de l'Oregon, des Californies et de la mer Vermeille. Paris, 1, 423.

Moyle, P. \& Orland, M. A. (2004). Essays on wildlife conservation. MarineBio Conservation Society. Retrieved December 10, 2014, http://marinebio.org/oceans/conservation/moyle/

Muir, J. J. \& Colwell, M. A. (2010). Influences of European beachgrass on snowy plover nest site selection. Condor, 112, 507-510.

Nichols, F. H., Cloern, J. E., Luoma, S. N., \& Peterson, D. H. (1986). The modification of an estuary. Science, 231, 567-573.

Nur, N., Page, G. W., \& Stenzel, L. E. (1999). Population viability analysis for pacific coast snowy plovers. Point Reyes Bird Observatory.

O’Neal, B. J., Heske, E. J., \& Stafford, J. D. (2008). Waterbird response to wetlands restored through the Conservation Reserve Enhancement Program. Journal of Wildlife Management, 72(3), 654-664. 
Page, G. W. \& Stenzel, L. E. (1981). The breeding status of the snowy plover in California. Western Birds, 12, 1-40.

Page, G. W., Stenzel, L. E., \& Kjelmyr, J. E. (1999). Overview of shorebird abundance and distribution in wetlands of the Pacific coast of the contiguous United States. The Condor, 101, 461-471.

Page, G. W., Stenzel, L. E., Page, G. W., Warriner, J. S., Warriner, J. C., \& Paton, P. W. (2009). Snowy Plover. The Birds of North America Online (A. Poole, Ed.). Ithaca: Cornell Lab of Ornithology; Retrieved December 10, 2016, from the Birds of North America Online: http://bna.birds.cornell.edu/bna/species/154

Paton, P. W. (1994). Survival estimates for snowy plovers breeding at Great Salt Lake, Utah. The Condor, 96, 1106-1109.

Paulson, D. (1993). Shorebirds of the Pacific Northwest. Washington: University of Washington Press.

Pearl, B., Tokatlian, K., \& Scullen, J. (2015). Western snowy plover monitoring in the San Francisco bay annual report 2015. San Francisco Bay Bird Observatory. Unpublished report.

Pearl, B., Tokatlian, K., \& Scullen, J. (2016). Western snowy plover monitoring in the San Francisco bay annual report 2016. San Francisco Bay Bird Observatory. Unpublished report.

Pearson, S. F., Sundstrom, C., Gunther, K., Jaques, D., \& Brennan, K. (2008). Snowy plover population monitoring, research, and management actions: 2008 nesting season research progress report. Washington Department of Fish and Wildlife. Unpublished report.

Pearson, S. F., Sundstrom, C., Ritchie, W., \& Gunther, K. (2009). Washington State snowy plover population monitoring, research, and management. 2009 nesting season research progress report. Washington Department of Fish and Wildlife. Unpublished report.

Pearson, S. F., Knapp, S. M., \& Sundstrom, C. (2014). Evaluation the ecological and behavioural factors influencing snowy plover Charadrius nivosus egg hatching and the potential benefits of predator exclosures. Bird Conservation International: 1-19.

Perry, M. Z. \& Henry, R. W. (2010). Recovering marbled murrelets via corvid management: a population viability analysis approach. Biological Conservation, 143, 2414-2424 
Powell, A. N., \& Collier, C. L. (2000). Habitat use and reproductive success of western snowy plovers at new nesting areas created for California least terns. Journal of Wildlife Management, 64(1), 24-33.

Raudsepp-Hearne, C., Peterson, G. D., Tengo, M., Bennett, E. M., Holland, T., Benessaiah, K., MacDonald, G. K., \& Pfeifer, L. (2010). Untangling the environmentalist's paradox: Why is human well-being increasing as ecosystem services degrade? BioScience, 60(8), 576-589.

Restani, M., Marzluff, J. M., \& Yates, R. E. (2001). Effects of anthropogenic food sources on movemements, survival, and sociality of common ravens in the Arctic. Condor, 103, 399-404.

Riensche, D. L., Gidre, S. C., Beadle, N. A., \& Riensche, S. K. (2015). Western snowy plover (Charadrius alexandrinus nivosus) nest site selection and oyster shell enhancement. Western Wildlife, 2, 38:43.

Robertson, B. A., \& Hutto, R. L. (2006). A framework for understanding ecological traps and an evaluation of existing evidence. Ecology, 87(5), 1075-1085.

Robinson-Nilsen, C., \& Demers, J. (2010). Western snowy plover numbers, nesting success, fledging success and avian predator surveys in the San Francisco bay, 2010. San Francisco Bay Bird Observatory. Unpublished report.

Robinson-Nilsen, C., Demers, J., \& Strong, C. (2011). Fledging success and avian predator surveys in the San Francisco bay, 2011. San Francisco Bay Bird Observatory. Unpublished report.

Robinson-Nilsen, C., Tokatlian, K., Scullen, J., \& Burns, C. (2013). Western snowy plover monitoring in the San Francisco bay annual report 2013. San Francisco Bay Bird Observatory. Unpublished report.

Rodenhouse, N. L., Sherry, T. W., \& Holmes, R. T. (1997). Site-dependent regulation of population size: a new synthesis. Ecology, 78, 2025-2042.

Rose, M. \& Nol, E. (2010). Foraging behavior of non-breeding semipalmated plovers. Waterbirds, 33, 59-69.

Rösner, S. \& Selva, N. (2005). Use of the bait-marking method to estimate the territory size of scavenging birds: a case study on ravens Corvus corax. Wildlife Biology, 11, 183-191. 
Rotella, J. (2016). Nest survival models. In E. G. Cooch \& G. C. White (Eds.), Program MARK: A gentle introduction (pp. 17-1-20 ). Fort Collins, Colorado: Colorado State University.

Roth, J. E., Kelly, J. P., Sydeman, W. J., \& Colwell, M. A. (2004). Sex differences in space use of breeding common ravens in western Marin county, California. The Condor, 106, 529-539

Ruhlen, T. D., Page, G. W., \& Stenzel, L. E. (2006). Effects of a changing environment on nesting snowy plovers at Owens Lake, California. Western Birds, 37, 126-138.

Ryan, T.P. \& Parkin, J. L. (1998). The western snowy plover (Charadrius alexandrines nivosus) in southern San Francisco bay. Summary of detections made during colonial waterbird monitoring surveys from 1981 to 1997 . Unpublished report.

San Francisco Bay Conservation and Development Commission. (2005). Salt ponds. Unpublished report.

San Francisco Bay Wildlife Society. (2015, October 2). Don Edwards (1905-2015) [Web log post]. Retrieved from http://sfbws.com/blog/2015/10/02/don-edwards-1905-2015

Sauer, J. R., Hines, J. E., \& Fallon, J. (2001). The North American breeding bird survey, results and analysis 1966-2000. Version 2001.2. U.S. Geological Survey. Unpublished report.

Schlacher, T. A., Dugan, J., Schoeman, D. S., Lastra, M., Jones, A., Scapini, F., McLachlan, A., \& Defeo, O. (2007). Sandy beaches at the brink. Conservation Science, 12(5), 556-560.

Schlaepfer, M. A., Runge, M. C., \& Sherman, P. W. (2002). Ecological and evolutionary traps. Trends in Ecology and Evolution, 17(10), 474-480.

Sekercioglu, C. H. (2006). Increasing awareness of avian ecological function. Trends in Ecology and Evolution, 21(8), 464-471.

South Bay Salt Pond Restoration Project. (2011). Annual report 2011. Unpublished report.

Steffen, W., Crutzen, P. J., \& McNeill, J. R. (2007). The Anthropocene: Are humans now overwhelming the forces of nature? AMBIO: A Journal of the Human Environment, 36(8), 614-621. 
Stenzel, L. E., Page, G. W., Warriner, J. C., Warriner, J. S., George, D. E., Eyster, . . Neuman, K. K. (2007). Survival and natal dispersal of juvenile snowy plovers (Charadrius alexandrinus) in central coastal California. The Auk, 124(3): 1023-1036

Tarjan, M. \& Butler, K. (2016). Citizen science- based colonial waterbird monitoring, 2016 nesting summary. San Francisco Bay Bird Observatory. Unpublished report.

Tokatlian, K., Scullen, J. \& Burns, C. (2014). Western snowy plover monitoring in the San Francisco bay annual report 2014. San Francisco Bay Bird Observatory. Unpublished report.

U.S. Fish and Wildlife Service. (1993). Threatened status for the Pacific population of the western snowy plover. Federal Register, 59, 12864-12874.

U.S. Fish and Wildlife Service. (2007). Recovery plan for the Pacific coast population of the western snowy plover (Charadrius alexandrinus nivosus). U.S. Fish and Wildlife Service, Sacramento, California, USA.

U.S. Fish and Wildlife Service. (2013). Recovery plan for tidal marsh ecosystems of northern and central California. U.S. Fish and Wildlife Service, Sacramento, California, USA.

Velasco, V. N. (2015). Investigation of non-lethal electric shock on American crows as a predator aversion treatment for reducing depredation on California least tern eggs. Unpublished thesis, Loyola Marymount University, Los Angeles, California.

Walker, L. E., \& Marzluff, J. M. (2015). Recreation changes the use of a wild landscape by corvids. The Condor Ornithological Applications, 117, 262-283.

Warnock, N., Page, G. W., Ruhlen, T. D., Nur, N., Takekawa, J. Y., \& Hanson, J. T. (2002). Management and conservation of San Francisco bay salt ponds: Effects of pond salinity, area, tide, and season on Pacific flyway waterbirds. Waterbirds, 25(2), 79-92

Warriner, J. S., Warriner, J. C., Page, G. W., \& Stenzel, L. E. (1986). Mating system and reproductive success of a small population of polygamous snowy plovers. Wilson Bulletin, 98, 15-37.

Webb, W. C., Boarman, W. I., \& Rotenberr, J. T. (2004). Common raven juvenile survivorship in a human augmented landscape. Condor, 106, 517-528.

Webb, W., Marzluff, J., \& Hepinstall-Cymerman, J. (2012). Differences in space use by common ravens in relation to sex, breeding status, and kinship. The Condor, 114(3), 584-594. 
Wilcox, B. A., \& Murphy, D. D. (1985). Conservation strategy: The effect of fragmentation on extinction. American Naturalist, 125, 879-887.

Worster, D. (1977). Nature's economy. Cambridge, United Kingdom: Cambridge University Press.

Wright, H. E. Jr. (1974). Landscape development, forest fire and wilderness management. Science, 186, 487-495.

Van Bael, S. A., Philpott, S. M., Greenverg, R., Bichier, P., Barber, N. A., Mooney, K. A., \& Gruner, D. S. (2008). Birds as predators in tropical agroforestry systems. Ecology, 89(4), 928-934.

Zarnetske, P.L., Seabloom, E. W., \& Hacker, S. D. (2010). Non-target effects of invasive species management: Beachgrass, birds, and bulldozers in coastal dunes. Ecosphere $1(5)$.

Zipkin, E. F., Sillett, T. S., Grant, E. H. C., Chandler, R. B., \& Royle, J. A. (2014). Inferences about population dynamics from count data using multistate models: A comparison to capture-recapture approaches. Ecology and Evolution, 4(4), 417-426. 